Received: 4 February 2021 Accepted: 17 February 2021

Keywords: Weddings; register offices; registered places of worship

\section{Interpreting choices: what can we infer from where our ancestors married?}

\author{
Rebecca Probert
}

Abstract: This article analyses a sample of 1,052 weddings reported by family historians as taking place between 1837 and 1952 in order to build up a picture of the characteristics of those marrying in a register office or registered place of worship under the Marriage Act 1836. It situates this data in the context of the national-level statistics in order to provide a more nuanced picture of the religious affiliation of those marrying in a registered place of worship and to determine whether those who married in the register office exhibited different characteristics to those who did not. It also analyses the changing legal framework in order to show how this determined the options that were available to couples at different times. Finally, it identifies what inferences can be drawn from the wording on the marriage certificate, for example whether a marriage is recorded as being conducted 'by' or 'before' a particular person or 'according to the rites and ceremonies of the parties'.

\title{
Introduction
}

In researching our ancestors' lives, it can often be difficult to determine what is worthy of note and what would have been normal for the time. Official statistics can only take us so far: in the context of marriage, for example, there are detailed statistics on how couples married from the advent of civil registration in 1837, but not on who opted for different types of marriages. But by pooling data it is possible to build up a more nuanced picture of who married where, and even to make some inferences as to why.

This collection represents the first findings from a body of data and stories shared by family historians. A call for information was disseminated via the Lost Cousins network and a number of societies interested in family history, ${ }^{1}$ asking two sets of questions:

\footnotetext{
Did any of your ancestors marry in a civil ceremony? If so, could you provide details of the location of the wedding, the age and occupation of the parties, and any reasons why they might have chosen a civil ceremony?
}

\footnotetext{
Were any of your ancestors Catholics or Nonconformists? If so, could you provide details of when and where they married - whether in a civil ceremony, Catholic or Nonconformist church, or in the Anglican church? If they did not marry in a place of worship that matched their religious affiliation, do you know why? ${ }^{2}$
}

Responses were received from 184 family historians about 1,132 marriages celebrated between 1837 and 2017. For the purposes of analysis, weddings involving living individuals were excluded, in line with the ethical approval for the study, and an end date of 1952 was chosen, to correspond with the availability of official data on how couples married. The final sample thus consisted of 1,052 weddings from across England and Wales.

Because the call for information was deliberately broad, rather than consisting of a closed survey, information was provided in a variety of ways. Some family historians submitted spreadsheets, some sent certificates, some shared stories, and some did all three. All of the information was useful in different ways, with some trends only becoming apparent after viewing a number of marriage certificates or a particularly comprehensive spreadsheet. All entries were coded to so that it could be checked that a particular trend was not limited to a particular family or locality. Where there was a risk that the inclusion of data might skew the results it was analysed separately: Liz Harris, for example, provided data on almost 700 weddings in Nonconformist chapels in Desborough which merited an article in its own right.

With examples from 44 counties, and from 290 different registration districts, any geographical bias should have been avoided.

(0) 2021 The Author(s). This is an open access article distributed under the terms of the Creative Commons Attribution License (http://creativecommons.org/ licenses/by/4.0/) 
This collection begins with an overview article analysing the trends in where couples married in the context of the changing legal framework and national-level statistics. It goes on to showcase a number of case-studies written by family historians - Christine Brumbill, Bryan Grimshaw, Susan Donaldson, Margaret French, Jenny Gordon, Wendy Hamilton, Kathy Irvine, Valerie King, Elizabeth Parsons, Jenny Paterson, Lesley Plant, Mike Sadler, Joan Smith, Deborah Whitehead, Jill Wright, and Peter Zimmermann - about marriages that are of particular interest either in illustrating wider trends or in highlighting the complexities that might underpin an apparently straightforward marriage ceremony.

This project would not have been possible without them, and the other family historians who so generously provided information: Adrian Abbott, Carol Abbott, Matthew Abel, Dawn Adams, Geoff Allan, Jenepher Allen, Tony Allen, Rosie Ansell, Colleen Armstrong-Thomas, Val Bachelor, Mary Barry, Pam Blackaby, Andrew Braid, Brian Brown, Chris Bourne, John Buchanan, Steve Bumstead, Anne Burns, Mary Butlin, Philip Carnall, Shirley Casey, John Cassidy, Jan Clemenson, Val Clinging, Robyn Coghlan, Barbara Cole, Julie Collins, Madeleine Cook, Judith Cooper, Alan Craxford, Helen Davies, Roger Davies, Sally Davies, Margaret Dennis, Marg Dolen, Norma Doling, Mary-Ann Dunn, M. Duxbury, Victoria Dyke, Teresa Eckford, Brian Ekins, Karen Eldridge, Lesley Eldridge, Hilary Elliott, Joyce Engmann, Noreen Evans, Karin Fancett, Janet Findlay, Sheila Fleming, Tom Flintham, John Godfrey Francis, Jennifer Fraser, Janet Freeman, Sue Frezza, Alison Galligan, Ann Gardner, Audrey Giacomin, Jon Gilbert, Pauline Gilbertson, Jenny Gordon, Julie Goucher, Pam Griffiths, Judith Gurney, John Hammond, Annette Harris, Sheila Harris (Constantine One Name Study), Kathy Hart, Elaine Hayes, David Heard, Yvonne Herne, Joan Hickey, Guy Hirst, Kate Holloway, Sarah Hughes, Tony Wakefield Hunt, Elaine Huq, Andrew R. Janes, Christine Jemmeson, Jill Johnson, Penny Keens, Elizabeth Kemshead, Rosemary Kennemore, Deborah King, Diana Kirkhope, Denise Langley, Stephen Larkin, Pam Laycock, Barbara Lee, Deirdre Leigh, Bridget Lewis, Jenni Llewellyn, Mike Lofty, Wendy Lynch, Ken Maidens, Beryl Malcolm, Chris Manning, Megan O'Marr, Joan Marshall, Nick Mayne, Anne Mead, Carol Metcalfe, Sara McMahon, Ruth Midgely, Jane Milbourne, Colin Moretti, Alun Morris, Janice Morris, Marion Moverley, Sheila Murray, Roger and Jenny McNae, Tony Newcombe, Pat Nixon, John North, Hilary Oldham, G.W. Oxley, Carol Parker, Sandy Pescod, Barbara Phillips, Pat Phillips, Brenda Powell, Sylvia Precious, Keith Preece, Mary Pringle, Wendy Rakestrow, Mary Ratcliffe, Judith Redfern, Susan Reeve, Dr Edward Reid-Smith, John Reynolds, Barrie Robinson, Diana Robinson, Sandra Robinson, Laura Rouse, Katy Russell-Duff, Ray Rylatt, Sandra Shaw, Ann Simcock, Mary Simpson, Shirley Small, Paul Smallcombe, John Smith, Sue Smith, Jeremy Somerton, Margaret Spiller, Colyn Storer, Janet Stroebel, Mrs Audrey Suthren, David Swidenbank, Carol Tarr, Karen Tayler, lan Terry, Eileen Thompson, Valerie Thorley, Marilyn Tilley, Kim Tomlinson, Linda Towne, Sandra Vincent, Lorraine Waldron, Angela Ward, Erica Ward, Mary Ward, Annette Watson, Barbara Watts, Jan Webb, Richard West, Irene Wilkinson, John Williams, Kay Winfield, John Wintrip, Peter Wood, Dave Wright, Jane Wright, Josephine Wright, and Mark Young. I would also like to thank Peter Calver for publishing the original call for information in his Lost Cousins newsletter.

\section{Law and Practice, 1837-1952}

On 1 July 1837, a new law came into effect. No longer was it necessary for all except Quakers and Jews to get married in the parish church. Under the Marriage Act 1836, weddings could take place in any certified place of worship that had been duly registered for marriages, or in the office of one of the newly appointed superintendent registrars. ${ }^{3}$ Although the take-up of these new options was initially low, by the end of the nineteenth century one-third of couples were choosing to marry according to non-Anglican rites, and by the mid-twentieth century around half did so. ${ }^{4}$

Behind the statistics lie millions of individual decisions by couples about where and how to marry. In most cases there will be no direct evidence of the reasons underpinning those decisions. This means that in drawing inferences about why couples married where they did, it is crucial to know what options were actually available to them in practice, and what these different options entailed. The fact that places of worship could be registered for marriages does not mean that all of them were registered, while the rules on what could be included in a register office wedding changed over time, as did the rules on who was required to attend a wedding in a registered place of worship. In order to show what options were available at different times, and the significance of choosing one or other of them, three different phases of the law will be examined. The first is the relatively short period between 1837 and 1856 when it was possible to have a religious ceremony in a register office as well as in a registered place of worship. The second is that from 1857 to 1899 , when having a religious ceremony in a register office was no longer an option but a civil registrar still had to be present at all weddings in registered places of worship. And the third is the period after the coming into force of the Marriage Act 1898 that enabled registered places of worship to appoint their own authorised persons to attend and register weddings in place of a civil registrar. There was, in other words, a sharpening distinction between register office weddings and those in registered places of worship, at least as far as the legal rules governing each are concerned.

Building up a picture of who availed themselves of these different options is more of a challenge. The official reports published by the Registrar-General detail how many weddings took place in Anglican churches, register offices, and registered places of worship. They also regularly provide figures for the number of buildings that had been registered by each denomination, and, from 1844, for the number of weddings in Catholic places of worship that had been registered for marriages. But detailed data on the number of weddings conducted in the registered places of worship of the many different Nonconformist denominations was not published until 1929, and then only sporadically before 1952. And while the reports detailed how many marriages were remarriages for one or both, or involved a bride or groom who was 
underage, these statistics were not broken down by type of marriage. In order to provide a more nuanced insight into who married in the register office or in a registered place of worship, this article draws on a sample of 1,052 weddings reported by family historians as taking place between 1837 and 1952: 624 in a register office, 357 in a registered place of worship, and 71 in an Anglican church but involving parties at least one of whom was Catholic or Nonconformist. ${ }^{5}$ Putting this data in the context of both the changing legal framework and national-level statistics shows who was likely to marry in a register office or registered place of worship rather than in the Anglican parish church and what inferences can be drawn from where individuals married at different times.

The key characteristics of those marrying in the register office are summarised in chart 1. 'Religion' encompasses those cases where one or both were reported as having a particular religious affiliation. 'Underage' includes those who were discovered to be under the age of 21 as well as those who were recorded as being under that age. 'Pre-marital' indicates that there was evidence of a pre-marital pregnancy, birth, or cohabitation. 'Remarriage' includes both legal and illegal second marriages and thus overlaps with the final category of 'impediment', where there was a legal reason why the marriage should not have taken place (for example if one of the spouses was already married).

Two preliminary points should be noted in relation to the data. First, the sample size for the earliest period is much smaller than those for the later periods - for 1837-1856, it comprises just 32 couples, as compared to 249 for 1857-1899 and 343 for 1900-1952. There is thus more scope for a small number of cases to make a big difference. Even so, the difference in the percentage reporting a religious affiliation is striking, and will be discussed further below. Second, the percentages do not add up to 100, whether because couples within the sample displayed multiple characteristics or because of the number displaying none of them.

\section{0}

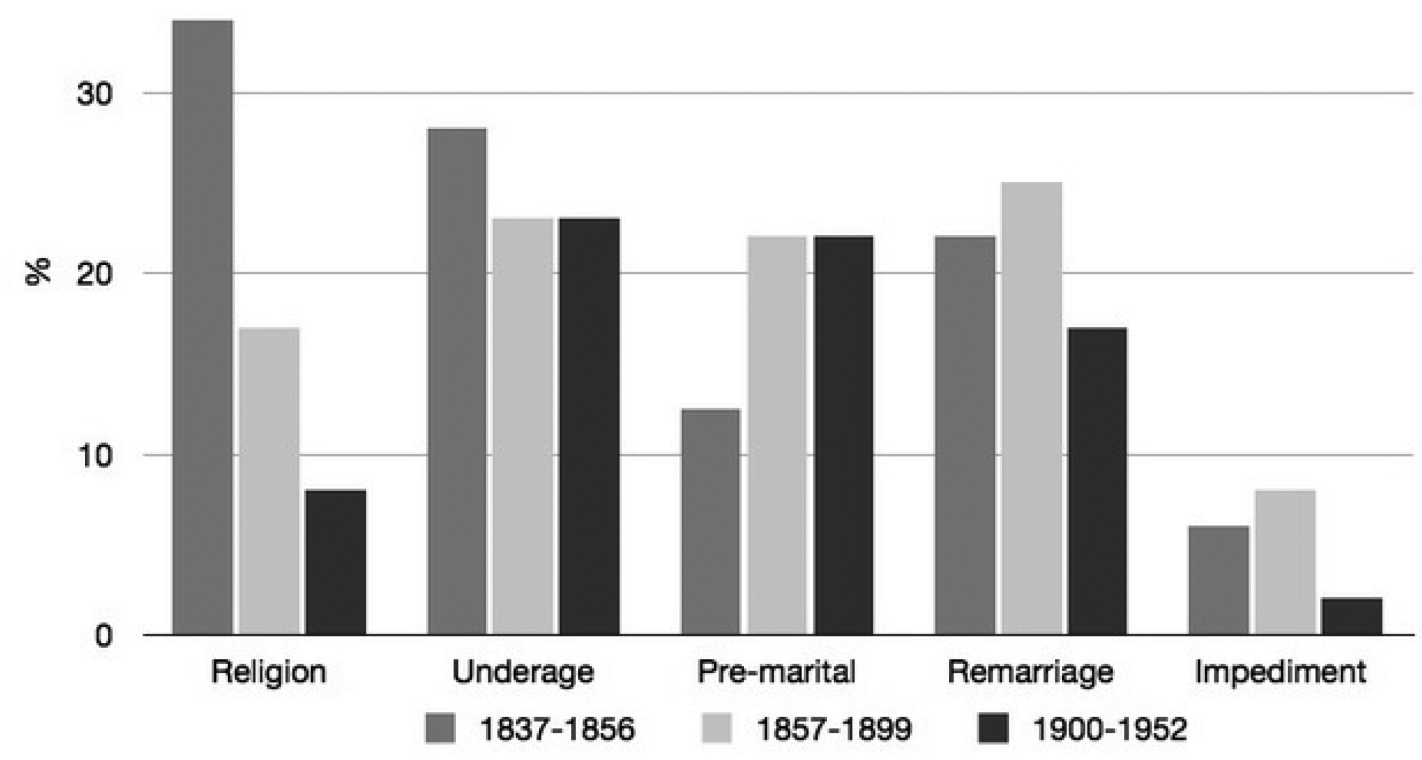

Chart 1. Characteristics of those marrying in the register office.

With those points in mind, we can now turn to the legal framework within which these choices were made.

\section{The early take-up of the Act, 1837-1856}

The Marriage Act 1836 made it possible for Catholics and Nonconformists to marry according to their own rites - but only if certain preconditions were met. Such weddings had to be preceded by giving notice at the register office, and had to be solemnised in the presence of a civil registrar, in a place of worship that had been registered for marriages. And in order for it to be registered, 20 householders had to certify that it was their usual place of worship, a fee of $£ 3$ had to be paid, and - unless it was Catholic - it also had to be a separate building. ${ }^{6}$

These requirements precluded many more modest places of worship from being registered. By 1851, 3,106 Catholic and Nonconformist places of worship had been registered for marriages, ${ }^{7}$ but that still left 16,860 that had not. ${ }^{8}$ While a couple could marry in a registered place of 
worship in a different registration district if none had been registered by their own denomination in the district(s) in which they lived, ${ }^{9}$ whether this was a realistic option in practice would have depended on the distances involved. In interpreting where couples married in the early years of the $1836 \mathrm{Act}$, then, it is worth bearing in mind just how many places of worship were not registered for marriages, and how this may have limited the options available to couples in any given locality.

The data from family historians suggests that a number of couples married in a register office who might have preferred to marry in a registered place of worship had this option been open to them. While the sample size for this period is small - family historians provided data on just 32 couples who married in a register office between 1837 and 1856 - it was striking that just over a third were identified as Nonconformist or Catholic. Of course, people's beliefs and affiliations may change over time, and it cannot be assumed that all of those who were not baptised in the Anglican church, or whose children were not so baptised, or who attended religious services elsewhere, would have married in a registered place of worship had the option been available to them. Nonetheless, if an individual was known to attend a particular place of worship, but married in a register office, it would be worth checking the London Gazette to see if and when that place of worship was registered for marriages. To give just one example, one man who married in the Preston register office in 1846 had been baptised at the Zion Chapel in Kirkham, ${ }^{10}$ but since this was only registered for marriages in 1849 he would not have had the option of marrying there. ${ }^{11}$

Two factors in particular would justify an inference that a particular couple would have preferred to have married in their place of worship rather than a register office. One is that they had a religious ceremony in the register office, as indicated by the marriage being recorded as taking place 'according to the rites and ceremonies of the parties'. ${ }^{12}$ If the marriage was also reported in the newspapers, there may even be details of the ceremony. ${ }^{13} \mathrm{~A}$ second is if the couple went on to have a separate religious ceremony in an unregistered place of worship. ${ }^{14}$

There are also a number of factors that might justify an inference that a couple getting married in a registered place of worship might have preferred to marry in a different place of worship. Under the $1836 \mathrm{Act}$, as long as the prescribed words were exchanged before the civil registrar it mattered not what else was said, or by whom. ${ }^{15}$ There was no legal requirement that any religious ceremony take place, or indeed that any religious celebrant be present. ${ }^{16}$ Again, there are examples of marriages being recorded as taking place 'according to the rites and ceremonies of the parties', indicating that the ceremony was not conducted according to the rites of the denomination who had registered the building. ${ }^{17}$ There are also examples of marriages being recorded as taking place 'before' the registrar, with the words 'according to the rites and ceremonies' being crossed out. ${ }^{18}$ In such cases it seems likely that no minister was in attendance and that the couple simply repeated the prescribed words in the presence of the registrar, as they would have done if marrying in the register office.

While some couples did not have the choice of marrying in their place of worship, others chose not to exercise that choice. Take-up was markedly more enthusiastic among Catholics than among Nonconformists in the early years: in the light of estimates that Catholics accounted for under 3 percent of the population in 1840s, while Protestant Dissenters accounted for around 20 per cent, it was striking that the nationallevel statistics show marriages registered as being solemnised in Catholic chapels accounting for between 25 and 44 percent of all marriages in registered places of worship between 1844 and $1853 .{ }^{19}$ Within the sample provided by family historians for the period, the percentage was 31 percent (see chart 2).

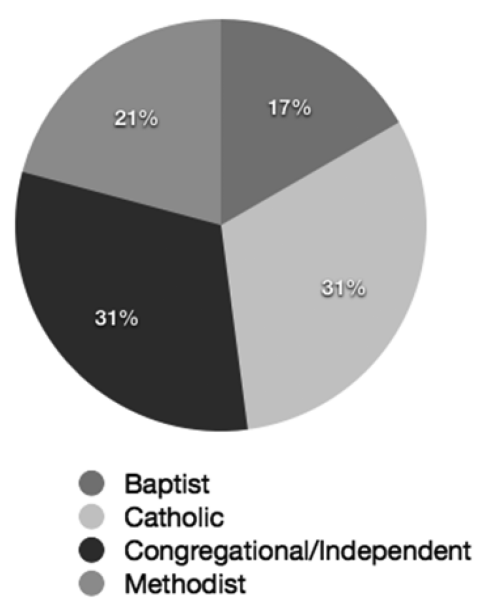

Chart 2. Marriages in registered places of worship 1837-56, by denomination $(n=50)$. 
Catholics, of course, had a long tradition of marrying according to their own rites, many having chosen to have an additional Catholic ceremony before or after their legally recognised marriage even before $1836 .{ }^{20}$ By contrast, Protestant Dissenters had no tradition of marrying in their own chapels, ${ }^{21}$ having previously simply married in the Anglican church. ${ }^{22}$ Given the novelty of the option of marrying in a registered place of worship, it is unsurprising that many of those who did so had a particularly strong connection with dissent. To take three examples from the sample: Matilda Ivory, who married in a Baptist chapel in 1845, was the daughter of the minister who conducted the service; ${ }^{23}$ Charles Duke and Elizabeth Beck, who married in a Wesleyan Methodist chapel in Hastings in 1855, went on to play a prominent role in the Methodist community in New Zealand; ${ }^{24}$ and Susanna Walter, an itinerant preacher for the Bible Christians, was the first bride to marry in their newly registered Providence Chapel in Northlew in $1850 .{ }^{25}$

The relatively slower take-up of the 1836 Act within Protestant denominations also reflected the fact that many Methodists - the largest nonAnglican denomination - did not regard themselves as Dissenters at all at this time. ${ }^{26}$ With only a tiny proportion of Methodist places of worship being registered for marriages, ${ }^{27}$ it is unsurprising to find many Methodists marrying in the Anglican church. Ralph Greenwell and Alice Hamilton, for example - whose attendance at the local Methodist church can be established through tickets preserved in the family bible - married at All Saints in Newcastle-upon-Tyne in $1847 .^{28}$

Of course, individuals' choices were shaped by a range of factors, not just by what was legally possible. Some would have married in the Anglican church because it was more convenient: since parishes covered a far smaller area than registration districts, more people would have lived within easy access of an Anglican church than of the register office. In addition, it was often cheaper to get married in church, at least so far as the legal costs were concerned. Conversely, there are indications that at least some couples may have chosen the register office because they wished to marry without attracting too much attention. Two of the marriages in the sample should not have taken place at all: in one case because the bride was the groom's deceased wife's sister, ${ }^{29}$ and in the second because the bride's husband was still very much alive. ${ }^{30}$ Seven brides and two grooms were underage. And at least three brides were pregnant, one of them giving birth just two weeks after the wedding. ${ }^{31}$ While prohibited marriages, underage marriages, and pre-marital pregnancy were hardly unique to the register office, far fewer examples were found among those marrying in a registered place of worship.

In this period, then, there was a considerable degree of fluidity between the various options. Marrying in the Anglican church did not necessarily indicate conformity, marrying in a registered place of worship did not mean that the couple were adherents of the denomination that worshipped there, and marrying in register office did not necessarily indicate any lack of faith. Perhaps the most important finding is that where a couple married may not always indicate how they married, with religious ceremonies being performed in register offices and nonreligious ones in registered places of worship.

\section{The sharpening of distinctions, 1857-1898}

Legislation in 1856 prohibited the inclusion of any religious service in a register office wedding, ${ }^{32}$ and required couples marrying in a registered place of worship to have the permission of the trustees of that building. ${ }^{33}$ Within the sample of marriage certificates provided by family historians, there were no further examples of marriages being conducted according to the rites 'of the parties', whether in a register office or registered place of worship. There were, however, still occasional examples of marriages being recorded as conducted 'before' the registrar in registered places of worship, with the reference to 'rites and ceremonies' being crossed out. One such marriage was that of a young widow, Hannah Carter, at the Old Meeting House in Stroud in 1872. That this was not the invariable practice is confirmed by the fact that the marriage of her son Henry at the same place some three years later was recorded as being 'according to the Rites and Ceremonies of the Congregationalists'. ${ }^{34}$ The most likely explanation of the disparity is that the minister was prevented from attending the 1872 wedding for some reason. The Liverpool Mercury noted in 1886 that 'it has happened more than once in Dissenting churches, that when the officiating minister has been prevented from attending, the registrar himself has married the couple, just as he would have done in his own office, without any religious observances whatever'. ${ }^{35}$

The second half of the nineteenth century saw more places of worship being registered for marriage, with the total reaching 12,285 by $1898 .{ }^{36}$ This meant that it was increasingly likely that individuals would have the option of marrying in their own place of worship. National-level statistics show that the percentage of weddings taking place in Catholic places of worship remained relatively steady over the course of the nineteenth century, at a little over 4 per cent; those taking place in Nonconformist places of worship, by contrast, increased from 7 per cent in 1857 to just over 13 per cent in $1899 .{ }^{37}$

Overall, however, Catholics were still the most likely to marry according to their own rites, as can be gauged from the fact that the percentage of weddings in Catholic places of worship was much closer to the percentage of the population estimated to be Catholic than was the case for Nonconformists. ${ }^{38}$ Within the sample, it was the desire of one Catholic couple to be married in their place of worship that was the trigger for it 
being registered. The marriage certificate issued to Thomas and Elizabeth Wilson by the Catholic church of St Joseph's in Reddish, Stockport, notes that their wedding, on 26 November 1888, was the first recorded there. The church had in fact been registered just a month earlier, on 27 October, ${ }^{39}$ and the story handed down through the generations is that the bride's father - Peter McClernon, a local businessman - was the one who paid the registration fee. ${ }^{40}$ Where a Catholic couple did not marry in the Catholic church there was generally a good reason: one couple, James Carter and Olivia Shotton, married in an Anglican church in Newcastle in 1876 - strategically over the river from where they lived in Gateshead - and two months later Olivia gave birth to their child. ${ }^{41}$

The increase in weddings in Protestant places of worship was largely driven by changing practices among Methodists. Methodist churches and chapels were increasingly being registered for marriages: by 1875 they accounted for 32 per cent of all registered places of worship ${ }^{42}$ and by 1898 for 42 per cent. ${ }^{43}$ There were still examples within the sample of Methodists marrying in the Anglican church - James and Martha Barnes, whose first son was baptised in the local Primitive Methodist circuit in 1883, had married in the parish church the previous year ${ }^{44}-$ but these were becoming increasingly rare. ${ }^{45}$ Of the 145 marriages reported as taking place within a registered place of worship between 1857 and 1899,50 , or 35 per cent, were Methodists (see chart 3).
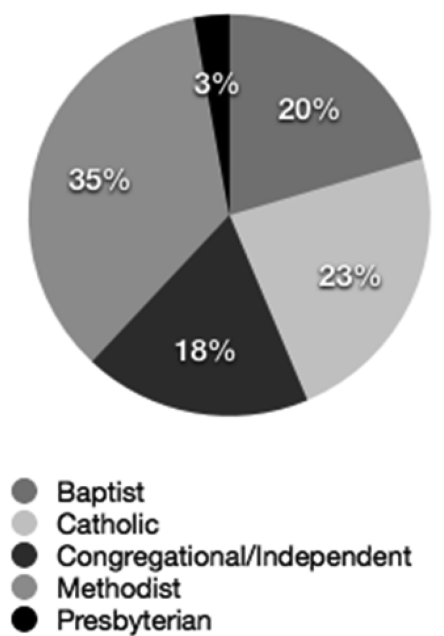

Chart 3. Marriages in registered places of worship $1857-99$, by denomination, $(n=145)$.

Examples included five of the children of Levi and Louisa Summers - who had themselves married in the Congregational Castle Hill Chapel in Northampton - who married in the Wesleyan chapel in Great Park Street in Wellingborough, ${ }^{46}$ five members of the Eastwood family, who married in the Bolton Brow Wesleyan Methodist chapel in Sowerby Bridge ${ }^{47}$ and two sisters who each married a Bible Christian minister in the same chapel on the same day. ${ }^{48}$

Despite the increase in registrations of places of worship, there were still a number that remained unregistered. In some cases this might be because they did not meet the legal criteria: in 1881, for example, the village of East Barsham in Norfolk had just 43 inhabited houses and a population of $180,{ }^{49}$ making it highly unlikely that its small Primitive Methodist chapel could be registered for marriages. ${ }^{50}$ Even so, with more places of worship being registered, couples whose own place of worship was not registered would not have had quite so far to travel to one that was. James and Albert Wilkinson, for example, were both teachers in the Sunday School run by the Primitive Methodist Chapel at Crich Carr, as were their respective brides, sisters Mary and Bertha Kirkland. At the time that they married - in 1899 and 1903 respectively - the chapel had not been registered for marriages, and so their weddings took place some six miles away in the Primitive Methodist Chapel at Cowhill, Belper, where Albert was a lay preacher. ${ }^{51}$

Within the sample, Catholics and Nonconformists accounted for just 16 per cent of register office weddings between 1857 and 1899 (see chart 1), and their profile was rather different from that of those who had married there in its early years. There were those who belonged to smaller denominations that had no registered place of worship close enough to marry in. ${ }^{52}$ A number were members of the Exclusive Plymouth Brethren, who had a very particular view of the relationship between religion and the state and refused to register their meeting houses for marriages. ${ }^{53}$ And in around a quarter of such cases the couple were from different denominations, usually with one being Catholic and the other Anglican. ${ }^{54}$ There are a number of possible reasons why such mixed marriages took place in the register office. It may have been that the neutrality of the register office was seen as offering the best compromise, meaning that neither had to compromise their own faith and marry according to the 
rites of the other. Another factor may have been the confusion that existed about the legitimacy of having two religious ceremonies, the 1856 Act having introduced a somewhat ambiguous provision which permitted a religious blessing to take place after a register office wedding but which was interpreted by some as outlawing such a blessing after a wedding in a registered place of worship or Anglican church. $^{55}$

The late nineteenth century also saw the first report of a register office wedding involving an individual who was explicitly opposed to religion. Alfred Radford, who married in Nottingham register office in 1882, had been raised in a strict Methodist family, but, in the words of his descendant, 'rejected this as an adult and did not raise his family in any religion. ${ }^{56}$ While the rarity of such views may reflect the difficulty of ascertaining the beliefs of earlier generations, it is worth noting that it has been estimated that only around 1 per cent of the population professed no religion at all at this time. ${ }^{57}$

Rather than couples marrying in the register office because they could not marry in a registered place of worship, or because they rejected religion, it would seem that for many couples the attraction of the register office was that it enabled them to marry quietly. Widows and widowers continued to be over-represented among those marrying in the register office, and there were also examples of those whose first marriage had ended in divorce. ${ }^{58}$ Some second marriages were void on account of an existing marriage or because the couple were related by a previous marriage. Most of the latter cases involved a widower and his deceased wife's sister, ${ }^{59}$ but there were also men marrying the niece or daughter of their deceased wife. ${ }^{60}$ Overall, 25 per cent of the 249 register office weddings reported by family historians as taking place between 1857 and 1899 were a second marriage for one or both of the parties, as compared to 17 per cent of all weddings, ${ }^{61}$ and 8 per cent should not have taken place at all on account of an impediment (see chart 1).

The percentage of register office weddings involving a bride or groom who was underage remained fairly consistent, at 28 per cent, but there was a significant increase - from 12.5 per cent to 22 per cent - in the percentage involving a pre-marital pregnancy, birth, or (more rarely) cohabitation. Many of the brides marrying in the register office would have been very noticeably pregnant; in one case the child was born just 12 days after the wedding, ${ }^{62}$ and in many others it was only a matter of a few weeks or a couple of months. Of course, in the absence of any national-level statistics on pre-marital pregnancy it is not possible to ascertain whether this increase was because more brides were pregnant or more pregnant brides were marrying in the register office. It is however worth noting that very few examples of pre-marital pregnancy, births, or cohabitation were reported among those marrying in a registered place of worship in this period. There is also evidence to suggest that at least some of these brides would not have married in the register office had they not been pregnant. One pregnant bride who married at Oldham register office in 1889 was the only one of her parents' seven children not to marry in the Independent chapel in the town where the family lived. ${ }^{63}$

Overall, then, the period between 1857 and 1899 saw a sharpening of the distinctions between the register office and registered places of worship. There were still some couples who married in a register office because they were unable to marry in a registered place of worship, but the fact that no religious rites could be included in the brief ceremony meant that the connotations of marrying in a register office changed. It was increasingly an option for those who had something to hide.

The trend towards marriage in the register office, 1900-1952

The shifting popularity of getting married in a registered place of worship reflected the changing religious profile of England and Wales. The passage of the Marriage Act 1898 - which allowed any registered place of worship to appoint its own authorised person to register marriages celebrated there in place of the registrar - made barely a ripple, since it made it no easier for a place of worship to be registered for marriages in the first place. The small increase in the percentage of weddings celebrated in Nonconformist places of worship - peaking at 14 per cent of all weddings in 1906 - can be attributed to an increase in membership of Nonconformist denominations. Both declined thereafter, and the national-level statistics show that by 1952 marriages in Nonconformist places of worship accounted for just 7.5 per cent of all weddings, and 45 per cent of weddings in registered places of worship. The Catholic population, by contrast, continued to grow, and marriages in Catholic places of worship similarly increased, in both real and absolute terms, accounting for 9.5 per cent of all marriages, and 55 per cent of those in registered places of worship, by $1952 .^{64}$

Within the sample, by contrast, most marriages took place in a Nonconformist place of worship (chart 4). 

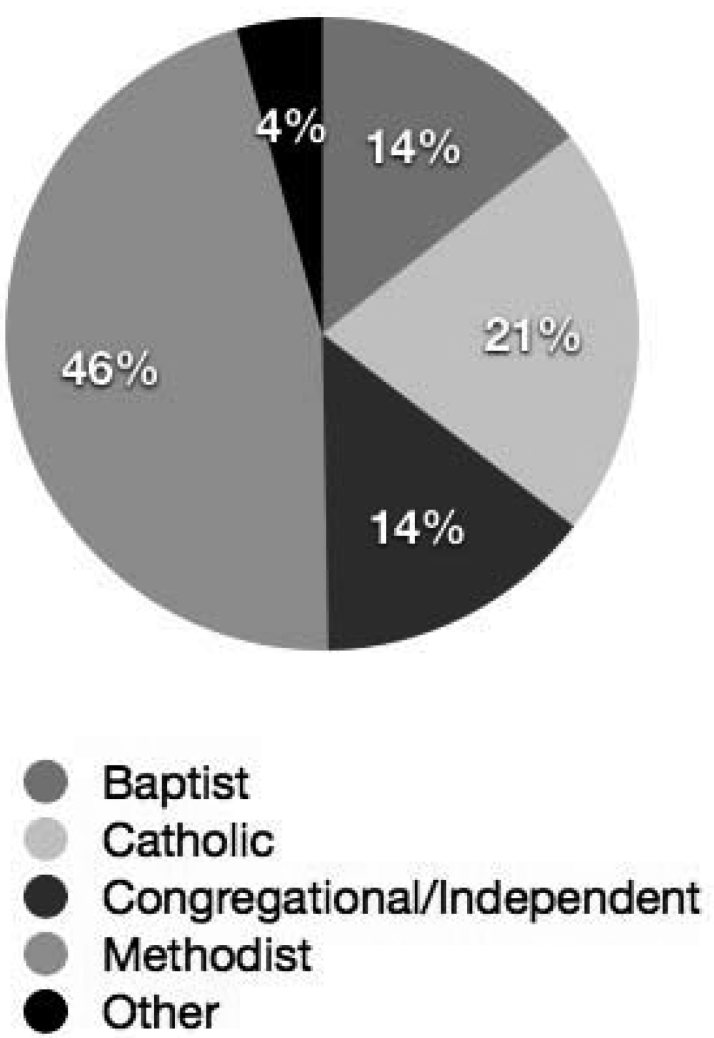

Chart 4. Marriages in registered places of worship 1900-52, by denomination, $(n=161)$.

With no national-level statistics available between 1934 (when 65 per cent of marriages in registered places of worship were Nonconformist ones) and 1952, and only sporadically available in the 20 years prior to that (for 1919, 1924, 1929), it is impossible to ascertain how representative this is, but it may indicate that the decline in marriages in Nonconformist places of worship took place towards the end of the period.

The data provided by family historians does allow some evaluation to be made as to continuity of allegiance to a particular religious group. On occasion such continuity of allegiance might be disguised by changing terminology. James Winfield had married according to the rites of the Wesleyan New Connexion in 1880, and his son Arthur married according to the rites of the United Methodist Church in $19133^{65}$ the latter organisation in fact represented a merger of the New Connexion with the Bible Christians and the United Methodist Free Churches that had taken place in 1907. Similarly, successive generations of the Moore family married in the same registered place of worship on the Isle of Wight, but earlier weddings were recorded as Bible Christian and later ones as United Methodist. ${ }^{66}$ Even taking such changes into account, it was noticeable that Catholic families demonstrated more consistency in terms of multiple members of the same family over different generations marrying in Catholic churches or chapels. The four children of Edward and Sarah O'Malley, who had married in a Catholic church in Stockport in 1908, all married in Catholic churches in the 1930 s and $1940 \mathrm{~s} .{ }^{67}$ There was also a further development that encouraged Catholics to marry in a Catholic church. On 19 April 1908 the decree of Ne Temere came into force, declaring that the Catholic Church would regard any Catholic who married in a register office, or in any non-Catholic place of worship, as not validly married at all. ${ }^{68}$

The most noticeable trend after 1900 was the increase in the number and percentage of weddings taking place in a register office. Over the first half of the twentieth century the percentage of such weddings doubled, rising from 15.3 per cent in 1900 to 30.6 per cent in $1952 .{ }^{69}$ The reasons behind this increase are complex, but the 343 register office weddings reported by family historians as taking place in this period show how practical considerations were particularly important.

Certain factors, it should be noted, became less important. A number of changes to the law reduced the number of couples that might need to resort to the register office to hide the fact that they were not legally entitled to marry. With restrictions on marriages to former in-laws being gradually removed, and obtaining a divorce becoming easier, only 2.6 per cent of register office weddings were reported as being void on account of a former or existing spouse (see chart 1). The percentage that involved a remarriage for one or both parties also dropped, to just 16 
per cent, only marginally higher than the 13 per cent of all marriages that were remarriages. ${ }^{70}$ There was, however, a significant difference in the nature of the remarriages that took place in the register office. Just 10 per cent of all remarriages in this period were recorded as involving a spouse who was divorced, ${ }^{71}$ but among the register office remarriages reported by family historians it was 45 per cent. Many of those who had been divorced may not have had the option of marrying according to religious rites, although some denominations were willing to conduct such remarriages. ${ }^{72}$ Given that the number of remarriages after a divorce was still relatively low, the greater likelihood that such remarriages would take place in a register office cannot by itself account for the rise in register office marriages. Nor was there any change in the percentage of register office weddings involving a pre-marital pregnancy, birth, or cohabitation.

The percentage identified as having a particular religious affiliation had halved again, to just 8 per cent (see chart 1). Of the 29 couples in question, five were members of the Plymouth Brethren, ${ }^{73}$ and 12 had different religious affiliations. As before, most of these were between Catholics and Protestants, ${ }^{74}$ but in one case a Jewish groom married an Anglican bride - providing a reminder that the legislative provision for Jewish marriages did not cover mixed marriages. ${ }^{75}$ In another case the bride was Christian and the groom was Hindu; ${ }^{76}$ the early twentieth century saw a number of marriages between Indian students and English women, but at that time no mosques, temples, or gurdwaras were registered for marriage. ${ }^{77}$

A more important factor in the rise of register office weddings may have been the decline in religious affiliation and attendance. ${ }^{78}$ There were some striking examples from family historians of individuals who rejected religion marrying in the register office. One London shoemaker, who married in the Kensington register office in 1909, told his family that the local church 'was on land stolen from the people.' His children were not christened, and he later objected to his grandson being christened too. ${ }^{79}$ Another man, whose RAF records show his religion as 'Church of Christ', nonetheless married in the Southampton register office in 1923 despite the local church of that denomination being registered for marriages. ${ }^{80}$ The choice of the register office may have been because his bride was illegitimate; alternatively, he may have lost his faith in the intervening years. Certainly, none of their seven children were brought up to attend church. ${ }^{81}$ And in one 1947 marriage - involving a Land Girl and a former German prisoner-of-war - the parties may have been influenced by the atheist views of the bride's sister and the groom's father. ${ }^{82}$

While the percentage of marriages in the register office was still far greater than the percentage of the population who had no religious belief, ${ }^{83}$ the weakening of religious affiliation and attendance may have made couples more willing to consider marrying in a register office where there were practical advantages to doing so in terms of the speed and cost of getting married. A superintendent registrar's licence, for example, enabled the waiting period between giving notice and getting married to be reduced to a single day. While this was no quicker than its ecclesiastical counterpart - which allowed a wedding to take place with no waiting period at all - it was considerably cheaper. During wartime in particular a number of couples availed themselves of this option: 28 per cent of the register office weddings reported by family historians took place between 1914-18 and 1939-45, and 60 per cent of these wartime weddings were by licence, as compared to just 28 per cent outside wartime. Respondents gave examples of the register office being used for a speedy wedding, for example where the husband was in the army and had a weekend's leave. ${ }^{84}$ Thus James Henry Pook, a sapper in the Royal Engineers, married by licence in Chatham Register Office in 1915 while on leave from the Western Front. ${ }^{85}$

For those on more limited budgets, marrying in the register office may also have been a way to avoid the ancillary costs of getting married. This was a factor that was specifically identified by a number of family historians as a potential explanation for a register office wedding in the twentieth century. As with issues of religious affiliation, it may be that they simply had more knowledge of more recent generations. It is however worthy of note that the class divide between those marrying in the register office and those marrying in a registered place of worship appeared to sharpen in the twentieth century. The overall proportion of grooms involved in broadly working-class occupations had been roughly the same in previous generations, even if those marrying in the register office were more likely to be involved in unskilled labour. For the period after 1900, while the percentage of grooms getting married in the register office who could be classified as working class remained the same, among those getting married in registered places of worship it almost halved. While more work remains to be done on the relative costs of getting married in a register office as compared to a registered place of worship or Anglican church, there are indications that the different expectations of the register office wedding would have had an impact on the cost of getting married there. As one contemporary guide advised, no wedding ring was needed for couples marrying in the register office, ${ }^{86}$ and early photos of those who married there suggest that there was no expectation of any special wedding attire. ${ }^{87}$

Overall, the first half of the twentieth century saw marriage in the register office becoming normalised, if not yet the norm. There were still a substantial number who married there for a specific reason - for example a pre-marital pregnancy or the fact that one of the parties was divorced - but there is also a sense of couples' choices being shaped by more practical considerations. 


\section{Conclusion}

Understanding the law tells us what is possible, an awareness of the national-level statistics shows us what is the norm at any given time, and looking at a large number of examples furnished by family historians helps to identify some of the reasons why couples married where they did. The significance of marrying in a registered place of worship or register office changed over time: between 1837 and 1856 they were essentially complementary options; between 1857 and 1899 there was an increasing divergence between them as the number of registered places of worship increased and the possibility of having a religious ceremony in the register office was removed; after 1900, the decline both in membership of Nonconformist churches and in religious affiliation more generally, together with considerations of speed and cost, and the increase in divorce, led to register office weddings overtaking those in registered places of worship.

But each couple had their own reasons for acting as they did, and the information shared by family historians underlined the importance of putting the marriage in the context of their life-story. We will now turn to case studies of individual weddings, which illustrate the complex interplay of factors that led to couples marrying in a particular way.

\section{A Catholic couple in the register office}

\section{Rebecca Probert}

On 1 March 1840, Thomas Brady and Mary Hetherington married in the Salford register office. ${ }^{88}$ This alone made them relatively unusual for their time. Across Lancashire, just 293 marriages were solemnised in a register office in the year to 30 June 1840-less than 2 per cent of the total (and this, if anything, was fractionally higher than the percentage across the country as a whole). ${ }^{89}$ But Thomas and Mary should not be seen as being in the vanguard of a more secular approach to marriage. There is a story behind their wedding that has considerable significance for our understanding of marriage law and practice in the early years of the Marriage Act of 1836.

Thomas and Mary had in fact wanted to get married in a Catholic chapel in the adjacent registration district of Manchester. ${ }^{90}$ The problem was that neither of them was resident in that district. The Marriage Act 1836 had not dealt with this particular contingency, and there were ambiguities in its drafting. It was clear that the bride and groom had to give notice in the district in which they were resident of their intention to marry -in Thomas and Mary's case this was Salford. ${ }^{91}$ It was also clear that a "superintendent registrar's licence" - the faster but expensive preliminary to a non-Anglican marriage—could not be granted for a marriage in a district where the couple did not live. ${ }^{92}$ But the Act said nothing about whether Thomas and Mary could be granted a "superintendent registrar's certificate" — the cheaper alternative-allowing them to marry outside the district where they lived. ${ }^{93}$

Nonetheless, registrars had been refusing to grant certificates under such circumstances, and the Registrar-General had supported them in their refusal. ${ }^{94}$ The Catholic Institute, concerned about the thousands of Catholics living in districts in which there was no Catholic chapel registered for weddings, used Thomas and Mary as a test case to challenge this particular interpretation of the Act. ${ }^{95}$ However, on 20 January 1840 the judge refused their application, ruling that the Registrar-General's interpretation of the Act was correct. ${ }^{96}$

Thomas and Mary, unable to marry in the chapel of their choice, and unwilling to marry in an Anglican church, had no choice but to marry in their local register office, in Salford. Intriguingly, though, on their marriage certificate it is clearly recorded that the marriage took place "according to the Rites and Ceremonies of the Parties". The implication is that they went through a Catholic ceremony in the register office.

This might seem surprising, given the assumption that register office weddings were by definition civil weddings. ${ }^{97}$ Yet marriage in a register office had not been conceived by lawmakers as a new form of purely secular marriage, but rather as an alternative option for religious Dissenters who did not wish to marry in an Anglican church. There was no prohibition in the 1836 Act on a religious service being used at a wedding in the register office. And there is evidence of other couples incorporating religious elements into register office weddings in these early years. ${ }^{98}$ Only in 1856 was any restriction on doing so imposed..$^{99}$

Some questions remain about the nature of Thomas and Mary's ceremony. Most certificates for register office weddings state that they were conducted before, instead of by, the registrar. ${ }^{100}$ It's a small but important difference that tells us a lot about what the role of the registrar was perceived to be. The certificate for Thomas and Mary's wedding, by contrast, records them as being married "according to the Rites and Ceremonies of the Parties", but "by" the registrar. Perhaps in this particular case the registrar felt the need to emphasise that he was responsible for actually solemnizing the marriage in the eyes of the law, even if a Catholic priest had conducted a marriage service.

If Thomas and Mary had waited a few months, they would have been able to marry in the Catholic chapel of their choice in Manchester. The Marriage Act of 1840 made it possible to marry in a suitably registered place of worship in a district in which neither of the couple lived, so 
long as there was nowhere of the same religious denomination in their home district. ${ }^{101}$ The person giving notice had to make a declaration as to their denomination and the ceremony according to which they wished the marriage to be solemnised, and confirm that there was no building within their district in which such a ceremony could be performed, as well as identifying where the marriage was to take place. ${ }^{102}$ Even so, the nearest registered chapel belonging to a couple's preferred denomination might be some distance away-registration districts could be large-and marrying there was not always realistic. But every district had a register office, and the case of Thomas and Mary shows that this could offer a genuine alternative—rather than a purely secular ceremony —in the early years of the 1836 Marriage Act.

\section{A "Catholic" marriage in the parish church?}

\section{Liam D'Arcy-Brown and Lesley Plant}

On March 16, 1845, a Falmouth sailmaker named James Rule married Mary Jones, in the parish church in Falmouth. Their marriage certificate records rather intriguingly that they were married "according to the Rites and Ceremonies of the Catholic Church, after Registrar's publication, by me, John Symonds curate". ${ }^{103}$ The Reverend Symonds had deliberately crossed out the word "Established" and replaced it with "Catholic". What are we to make of this? Had James and Mary been married in an Anglican church according to the rites of the Roman Catholics? And why had they given notice of their intended wedding to the superintendent registrar rather than have the banns called in church?

The first thing to consider is the possibility that James and Mary had been married by a Roman Catholic priest in an Anglican church. This is quite easy to rule out: John Symonds is duly listed in The Cornwall Register, ${ }^{104}$ a detailed directory of the Anglican parishes of Cornwall and their clergy. If Symonds had been a Roman Catholic priest, the Marriage Act 1823 specified that any marriage conducted in an Anglican church other than by an Anglican clergyman was void if the couple marrying were aware of the fact. ${ }^{105}$

What about the possibility that the Reverend Symonds had married James and Mary using the marriage liturgy of the Roman Catholic church? After all, the 1823 Act directed Anglican clergymen to use the Book of Common Prayer but stopped short of invalidating marriages which strayed from it. ${ }^{106}$ It is, nevertheless, hard to imagine that James and Mary might unwittingly have married in a ceremony conducted (as Roman Catholic marriages were) in Latin, or that Symonds would have wished for the furore and ecclesiastical censure which such an act would have brought down upon his head. And if James and Mary had wanted a Roman Catholic ceremony, they could after all have gone to Falmouth's Roman Catholic chapel: Historical Notes on English Catholic Missions records that Falmouth's first Roman Catholic chapel opened in 1805 , and that in 1821 a larger chapel replaced it. ${ }^{107}$

What then are we to make of this mention of "the Catholic Church"? The answer lies in a sermon preached by the rector of the parish, the Reverend WJ Coope, in Helston in $1842 .{ }^{108}$ Dedicated to the Bishop of Exeter, a man sympathetic to Coope's High Church views, it was an extended discussion of Jesus's words "Ye are the salt of the earth" and the application of this metaphor to the Christian Church. Coope's belief that the Church of England had been chosen by God to spread Christianity by means of Britain's expanding Empire is abundantly clear. For Coope, the Church of England was not one of those Protestant denominations which traced their roots to the Reformation and were free to innovate; instead, it was a direct inheritor of the traditions of the one holy Catholic Church of Christ—a phrase he used repeatedly in his sermon. Coope was not a Roman Catholic but an Anglo-Catholic.

As such he had introduced a number of changes to the form of worship the congregation had been used to. As an article in The Spectator magazine noted, "Falmouth is added to the list of parishes torn by Church dissensions and it appears to have been so for a long time". ${ }^{109}$ Coope had taken to parading up the aisle to the communion table and had installed a small tap in the font, so that what he considered to be "consecrated and holy" water could be emptied onto the floor without its being rudely ladled out. He had read prayers with his back facing the congregation, installed gilt candlesticks and large crosses embroidered in gold, worn a surplice, and chanted parts of the service. He had begun to conduct marriages at the centre of the church, where the transepts and the nave formed the shape of the Cross. Coope's changes had struck his parishioners as being far too close to Roman Catholicism for comfort. Some 270 of the great and the good had signed a letter of complaint, but the Bishop of Exeter had done little.

In 1843, Coope had left his restive parish behind and escaped to Florence, naming John Symonds as curate. When it came to the changes which Coope had brought in, though, "Mr. Symonds [felt] bound to await orders from his Rector". ${ }^{110}$ When Symonds amended "Established Church" to "Catholic Church" in the marriage register, he was confirming Coope's (and perhaps his own) beliefs.

There is also the separate question as to why James and Mary decided to give notice of their marriage to the superintendent registrar rather than have their banns called in church. The Marriage Act 1836 allowed marriages in the Church of England to be preceded by giving notice to a superintendent registrar, ${ }^{111}$ but a mere $1.3 \%$ of the 129,515 couples married in England and Wales that year chose this route. ${ }^{112}$ As James and Mary had already had a child together - born in September $1842^{113}$ - they may have been reluctant to have advertised their belated plans 
to marry. James, it should be noted, may not have been able to marry Mary at that time: the 1841 census records him as an 18-year-old apprentice, ${ }^{114}$ and either parental disapproval or the terms of his apprenticeship may have been an obstacle to his marriage. The alternative of marrying in the register office was likely to have been an unattractive one, given that the superintendent registrar for Falmouth, Mr William James Genn, conducted weddings in the nearby office which he also used in his capacity as the town's coroner. ${ }^{115}$

The marriage of James and Mary illustrates how an understanding of local factors can be crucial in understanding our ancestors' marriages and how individual cases can shine a light on the great issues of the day.

\section{The four marriages of John Allwright, 1826-1915}

\section{Deborah Whitehead}

John Allwright was born in Chesham, Buckinghamshire in $1826 .{ }^{116}$ His parents and grandparents were active Congregationalists, worshipping at the Independent Chapel in Chesham. We know this, firstly, because this chapel handed in its registers around 1837 when civil registration began. They are now in the National Archives, and have been scanned and indexed and can be viewed on the Family Search website. Allwright baptisms and burials can be seen in the registers. Secondly, John is recorded as giving an address in the Congregationalist Chapel in a local newspaper report of $1880,{ }^{117}$ and there are reports of his daughters taking part in the annual Good Friday musical evenings at the chapel around the same time. ${ }^{118}$

It is interesting to note that the Victoria County History for Buckinghamshire, published in 1925, tells us that 'Chesham is a stronghold for Nonconformity'. ${ }^{119}$ Like many Independent chapels, the one in Chesham was quick to register itself for marriages under the Marriage Act 1836, and marriages could take place there from late August $1837 .{ }^{120}$

However, John's first marriage was not in this chapel. On 12 November 1846 he married Mary Hawes in the Lower Baptist Chapel at neighbouring Amersham, Buckinghamshire. They were married 'according to the Rites and Ceremonies of the Protestant Dissenters' by the Registrar, James Dorrell. ${ }^{121}$

Mary's birth (and those of her siblings) was recorded at the Old Baptist Meeting House in Chesham. ${ }^{122}$ Although she and John were of different Nonconformist denominations, it seems that the marriage was agreeable at least to John's family, as his father, Henry Allwright, signed as witness. It also appears that Mary's religion prevailed in the choice of chapel, as the wedding took place in a Baptist rather than Congregationalist chapel. It is not, however, clear why it did not take place in Chesham where both parties lived, but in Amersham instead, especially as the Old Baptist Chapel was registered for weddings. It may be that Amersham was more convenient for the Registrar, who was recorded in the 1841 census as living on the High Street in Amersham. ${ }^{123}$

Sadly, Mary died in 1849, presumably due to causes related to childbirth, as the birth and death of a son, Maurice, is registered in the same quarter as her death. ${ }^{124}$

In 1852, John took the plunge again, and married Susannah Saywell on 13 April. This time he married on home territory, in the Independent Chapel in Chesham. They were married 'according to the rites and ceremonies of the Churches of the Independent Body' by W.J. Bain, and the certificate is countersigned by Arthur Clarke, Registrar. ${ }^{125}$ Arthur Clarke was one of the two registrars for Amersham at this time, alongside George Washington Morris, James Dorrell having died by then. ${ }^{126}$

Susannah had been baptised in the Church of England, so she may have joined the Congregationalists at some point, or agreed to marry in a Congregationalist Chapel because it was important to John. Unfortunately, Susannah died in 1862 of 'hysteritis [inflammation of the womb] after delivery of adherent placenta' - another pregnancy-related death. ${ }^{127}$ This left John with four daughters to bring up on his own, so it is not surprising that he remarried two years later.

Perhaps he wanted to be sure there would be no possibility of another wife dying in childbirth, as his next marriage was to a woman 15 years his senior, 53-year-old widow Elizabeth Hovey. Again, this was in the Independent Chapel at Chesham 'according to the rites and ceremonies of the Independents' by Joseph Hony Snell, Minister, in the presence of George Washington Morris, Registrar. ${ }^{128}$ As noted above, Morris served as registrar alongside Clarke.

Elizabeth Hovey, nee Barber, was the widow of John Hovey, a painter and decorator. In the censuses she gave her birthplace as Chesham or Tring, Hertfordshire, ${ }^{129}$ and on her marriage certificate gave her father as Thomas Barber, a weaver, but I have not found a baptism for anyone meeting 
these criteria. Her marriage to John Hovey in 1828 had taken place in the Church of England, ${ }^{130}$ but since all marriages had to take place in the Church of England in 1828, except Jewish or Quaker ones, this doesn't necessarily mean she worshipped in the Church of England at that time.

John's third marriage lasted around 18 years, until Elizabeth's death in $1882 .{ }^{131}$ Two years later, he remarried for a fourth and final time, to Elizabeth Cato. Elizabeth had not been married before. I cannot find a baptism for her, so do not know what faith she practised, but again the marriage took place at the Independent Chapel in Chesham on 3 April 1884, 'according to the rites and ceremonies of the Independents' by John Pither, the minister, and Thomas $\mathrm{H}$. King, registrar. ${ }^{132}$ King, who was a chemist as well as a registrar, had replaced Morris by this time, although Clarke was still in post. ${ }^{133}$

Elizabeth died in 1912 aged $84,{ }^{134}$ and John outlived her by around three years, dying in 1915 aged $88 .{ }^{135}$ His wives had obviously looked after him well.

Looking at John's four marriages, it appears that his choice of marriage place prevailed in each case, except in that of his first wife, who was a Baptist. It is however possible that his subsequent wives may have become Congregationalists before they married him, so the wish to marry in the Independent Chapel was mutual.

It is also worth noting that his first marriage was apparently conducted 'by' the Registrar, with no mention of a Minister, whereas the others mention the Minister first and then the Registrar, as if the Registrar was more of a witness than an officiant. The latter approach was in line with the way that the role of the Registrar was set out in the Marriage Act 1836: his role was simply to be present, and to register the marriage. ${ }^{136}$ How the marriage was conducted was left up to the couple themselves, the Marriage Act 1836 having specified that marriages could be solemnised in the registered places of worship 'according to such Form and Ceremony as they may see fit to adopt'. ${ }^{137}$ As long as the prescribed words ${ }^{138}$ were exchanged it mattered not what else was said, or by whom.

\section{A bigamous marriage in the register office}

\section{Elizabeth Parsons}

On 13 September 1853 Charlotte Vicary, aged 18, and Charles Farrant, aged 19, were married in the Independent Chapel at Sidbury, Devon. ${ }^{139}$ Their daughter, Thirza, had been born the month before, on 12 August $1853 .{ }^{140}$ It may be that one or both of them entered into the marriage reluctantly, persuaded by their respective families that it was the right thing to do. Just how long they remained together is unknown. There are no records of any other children being born to the couple after 1853. It is possible that Charles Farrant abandoned his wife and daughter which, in the middle of the nineteenth century, might have left Charlotte in very difficult circumstances. What we do know is that six years later Charlotte married again, this time at the Register Office in Exeter. ${ }^{141}$

Since Charles was still alive in 1859 , this second marriage was void. It was also bigamous. ${ }^{142}$ Even if she and Charles had separated immediately after their wedding, Charlotte would not have been able to satisfy the seven-year defence. ${ }^{143}$ The only basis on which she might have convinced herself that she was entitled to marry again was if she had been coerced into her first marriage. Duress was recognised as invalidating a marriage, but the threshold was set at a high level. ${ }^{144}$

In any case, the circumstances of her second marriage suggest an attempt at concealment rather than a belief that she was entitled to remarry. First, there is the fact that the wedding took place in Exeter. Since both Charlotte and her second husband James lived in Sidbury, they were within Honiton registration district. The law required couples to give notice, and to marry, in the registration district where at least one of them had been resident for the previous seven days. ${ }^{145}$ There were limited exceptions for those who wanted to marry in a particular place of worship, ${ }^{146}$ but no exceptions for those marrying in a register office. However, Charlotte may have worried that her name would be recognised at the Honiton register office. Either she or Charles would have had to give notice there in 1853 prior to their marriage in the Independent Chapel. In 1859 Honiton's superintendent registrar was Horace Vibart Mules, who not only had been acting as deputy in 1853 but had also been the clerk to the Union. ${ }^{147}$ It was Horace who would have read her name out to the Board of Guardians on three separate occasions prior to her first marriage. ${ }^{148}$ Getting married in Honiton registration district was just too risky.

Whether Charlotte and James were actually resident in Exeter for seven days prior to giving notice of their intention to marry is open to doubt. In any case, since they gave their address as the Artillery Inn on Holloway Street, it must have been obvious to the superintendent registrar that they were temporary rather than permanent residents. They might simply have claimed that they had been there for the seven days: after all, there was no requirement to provide proof of their address. 
The marriage certificate also shows that they lied about a number of other facts. Charlotte used her married name of Farrant, as she was entitled to, but claimed to be a spinster and altered her father's name to match. Her husband's name was recorded as James Deem, whereas his actual surname was Page. The fact that both gave false details suggests that James was fully aware of Charlotte's first marriage.

The fact that Charlotte and James were able to marry away from their home, giving misleading details about their identity, underlines just how ineffective the system was in preventing illegal marriages from taking place. The law had changed between Charlotte's first and second marriages. No longer were notices of marriage read out before the meetings of the Board of Guardians on three occasions prior to the marriage taking place. Instead, the notice of the intended marriage was simply displayed in the office of the superintendent registrar. ${ }^{149}$ The superintendent registrar for Exeter at the time was James Terrell, a solicitor, and the register office was in the house that served as both his home and his workplace. ${ }^{150}$ Even if the notice of Charlotte's intended marriage was, as the law required, displayed in some 'conspicuous' place within the office, it would not have garnered much attention.

After the wedding, Charlotte and James returned to Sidbury. The census return for 1861 records the family - including Charlotte's daughter Thirza, two further children, and James's father - under the name of Page. ${ }^{151}$ By 1871 they had another three children, and Charlotte's father was living with them. ${ }^{152}$ Clearly this was a marriage that was sanctioned by their respective families, even if it had no standing in the eyes of the law.

\section{A simple register office wedding}

\section{Elizabeth Parsons}

On Sunday 9 October 1859 Edwin Rice, aged 22, and Elizabeth Hawker, aged 27, were married by licence at the Register Office in Stoke Damerel, Devon. ${ }^{153}$ They were part of a growing trend. 1859 saw the number of register office weddings passing the 10,000 mark for the first time. ${ }^{154}$ While still very much a minority - register office weddings accounted for only 6.4 per cent of all marriages in England and Wales in that year - the number had almost doubled in the preceding decade. ${ }^{155}$ Edwin and Elizabeth's wedding illustrates some of the reasons why.

In an increasingly mobile society, where couples might be living and working many miles from their family, a register office wedding offered a simple way of tying the knot. Neither Edwin nor Elizabeth was originally from Stoke Damerel. Edwin's family home was in Sowton, while Elizabeth had been born in Clyst St George. ${ }^{156}$ Both villages were near Exeter, just a few miles apart, and it is possible that the couple had met while still at home and kept in touch after taking up their employment in South Devon. However, returning to their home parishes to marry would not have been an option, as at least one of them would have needed to establish residence for the purpose of having the banns called or obtaining a licence.

Elizabeth did at least have her sister and brother-in-law present at the wedding - as evidenced by the fact that they signed as witnesses. They too were living in Devonport at this time, so it would have been easy for them to attend. It seems unlikely that other members of the family would have travelled to attend what was a very short legal ceremony.

Edwin and Elizabeth were also living some distance apart at the time of their wedding. Edwin was a Gentleman's Gardener, working at Gorway, East Teignmouth, while Elizabeth was a Lady's Maid. Their respective occupations prompt a further romantic conjecture about how they may have met: perhaps the Lady, accompanied by her Maid, visited the Gentleman at Teignmouth and the couple met in the garden of the Estate. From a legal point of view, the fact that they were resident in different districts made a register office wedding a convenient choice. A change in the law in 1856 meant that if a couple were marrying by licence then, as long as one of the couple had been resident in the registration district where the marriage was taking place for the preceding fifteen days, the other did not have to give notice in their own registration district. ${ }^{157}$ By contrast, had they chosen to marry in Elizabeth's parish church, Edwin would have had to have arranged for his banns to be called in his own parish as well. While obtaining a licence from the ecclesiastical authorities would have removed that necessity, ecclesiastical licences were more expensive than their civil counterparts. The changes made in 1856 had also seen the cost of a civil licence being slashed from $£ 3$ to $£ 110$ s. ${ }^{158}$

The combination of the changes in 1856 suddenly meant that marrying in a register office providing a way of marrying more quickly, quietly and simply than by banns, and more cheaply than by ecclesiastical licence. Elizabeth was living at 47 King Street, Devonport at this time and would have had easy access to the register office in order to give notice of their intended marriage. Stoke Damerel is a district of Devonport in Plymouth, and its register office was then located at 20 Fore Street, just a mile from King Street. Since the marriage was by licence, the notice would only have needed to have been displayed for a single day. ${ }^{159}$ She could have given notice on the Friday, with the wedding planned to take place on the Sunday. 
With no need to establish residence in the district, Edwin might even have travelled to Devonport on the day of the wedding. In 1859 there was already a railway station at Newton Abbot - which is very near Teignmouth - with a train connection to Plymouth.

While Edwin and Elizabeth's story is a very simple one, its very simplicity helps to illustrate why marriages in the register office were an increasingly popular option following the changes made in 1856.

\section{Susan Darke: a puzzling chapel marriage}

\section{Joan Smith}

My family had a long-standing connection with the Independent Chapel in Honiton (variously referred to as either the Old or New Independent Meeting House). In 1837, when the Minister was depositing the registers of Baptisms, ${ }^{160}$ he said he had received its 'register' from John Darke, by then deceased, who had held the post of Clerk to the Chapel in succession from his father, grandfather, and great grandfather. John Darke was my 5x great-grandfather and this document connected my ancestors with the Chapel from the late seventeenth century. Baptismal records for the name Darke at the Chapel begin with David Darke in 1698.

The Chapel was one of the earliest of the many thousands of nonconformist chapels to be registered for marriages under the Marriage Act 1836. The London Gazette records that it was 'duly registered for solemnising marriages therein' on 30 September $1837 .^{161}$ The first of the annual reports published by the Registrar-General show that only 619 chapels had been registered by this date. ${ }^{162}$

Having expanded my Darke research to include all John's grandchildren (named in his will, which was written in 1835), I discovered that the daughter of his son Peter, Mary Ann, had married Matthew Newberry there in 1853. The marriage was performed by William Evans Foote 'according to the Rites of the Independents' and was countersigned by John Knight, Registrar. ${ }^{163}$ This was exactly what I expected given the family's long-standing association with the chapel. It was also useful confirmation of family relationships, as Mary Ann's father's name and occupation fitted and one of the witnesses was her sister Hannah.

Mary Ann's other sister Susan, however, proved harder to trace. Susan Darke, daughter of Peter Darke and his wife Susanna, was baptised at the Honiton chapel in $1821 .{ }^{164}$ She was probably 3 years old at the time, and her brothers James and Israel were baptised on the same day. In 1836 Susan Darke had her illegitimate daughter Sarah Ann, baptised at the Honiton Parish Church. They appear together in the censuses for both $1841^{165}$ and $1851^{166}$ living with Susan's father Peter.

I also found Susan in the 1861 census aged 40 and working as a Servant in Sidmouth. ${ }^{167}$ At this stage, however, the trail ran cold and without the benefit of the now available 'Ancestry Hints' I could find no further record of her. I checked death records and the marriages in the parishes surrounding Honiton and Sidmouth without success.

I however did find a reference for a marriage of a Susan Darke in the Honiton registration district in 1864. Back in 2003 it was cheaper to obtain copies of certificates from the local registry office so I promptly wrote to Honiton with all the details and the current fee. Weeks passed and eventually I phoned and asked if my request had gone astray. The office told me that they had checked all the venues for whom they had registers and could not find the certificate, and asked if I could supply more details to help them locate the certificate. I explained about the connection with the Chapel in Honiton High Street and the Registrar confirmed that the marriage did not take place there. Then there must have been a light bulb moment and within a couple of days a certificate arrived. It confirmed that Susan, a 47-year-old spinster, married at the Wesleyan Centenary Chapel Fenny Bridges, a venue the current superintendent registrar said had hosted very few marriages. It confirmed I had the right Susan as her father's name and occupation were correct. ${ }^{168}$

Yet this discovery raised a whole host of new questions as to why Susan had married in that particular chapel. According to the certificate Susan and her husband-to-be, a 51-year-old widower named John Colesworthy, were both living in Sidmouth at the time of their marriage. It would have been around 8 or 9 miles for them to Fenny Bridges and a further 4 miles on to Honiton. It would be understandable if they had thought 12 miles too far to travel to get married, particularly as the wedding had to take place before noon. Yet convenience alone cannot explain the choice of chapel, since there was an Independent Chapel in Sidmouth that had been registered for marriages. ${ }^{169}$

One possible explanation is that Susan had switched her allegiance to the Wesleyan Methodists or that her husband-to-be belonged to this denomination. Given how few Methodist chapels were registered for marriage at this time, ${ }^{170}$ it is not surprising that she had to travel some distance in order to marry. 
There was however one further little puzzle. No minister was mentioned on the marriage certificate as performing the marriage and there was nothing about how the marriage was celebrated. The certificate was simply signed by the registrar, John Knight - the same person who had signed Mary Ann's certificate 11 years earlier. And the printed word 'by' was crossed out, with the word 'before' being substituted.

The significance of this lies in the fact that weddings in the register office were almost invariably described as being 'before' the registrar and superintendent registrar, ${ }^{171}$ save in those few cases where there was also a religious ceremony in the register office. ${ }^{172}$ So did Susan and John have a religious ceremony at all, or did they just repeat the prescribed words in the presence of the registrar?

There is yet another intriguing possibility. There are 2 witnesses to the wedding - James Darke, Susan's brother, and a James Cooper. I did not recognise the name James Cooper and decided he was probably not connected to the Darke family. I returned to the 1861 census and looked at all the James Coopers living in Devon. I found one living in Topsham - who was described as a Unitarian Minister. ${ }^{173}$ While there was a Unitarian Chapel registered for marriages in Sidmouth at the time (the Old Dissenting Meeting House), the journey from Topsham to Fenny Bridges was easier than that from Topsham to Sidmouth. And it was not unknown for nonconformist chapels that were registered for marriages to allow weddings according to the rites of other denominations to take place there.

Exactly how the wedding was celebrated, and by whom, will have to remain a matter of speculation. But Susan Darke's case illustrates how important it is to look at the options that were available to our ancestors when getting married - both legally and geographically - and to think about every word on the marriage certificate.

\section{The Plymouth Brethren and register office weddings}

\section{Jill Wright}

"Of course Brethren wouldn't marry in another church or allow the State to register their own meeting rooms" said my husband when I expressed surprise that his parents had married in a register office. ${ }^{174}$ Like many, perhaps, I had assumed the majority of such weddings were for those who had no religion or divorcees. His family had been members of the Exclusive Brethren until further scandals about the leader J. Taylor, and yet more edicts that threatened family contact, finally made them leave in the 1960s. I remembered this comment when I began researching the family and found some surprising early marriages in register offices.

The reason for these register office weddings, as my husband's comment indicated, was not simply that the couple's local place of worship happened not to be registered for marriage, but a deliberate choice within the organisation not to register their Meeting Rooms at all. The Brethren movement had started in Dublin in the late 1820s as a break-away from the Anglican Church. Key elements were to get 'back to the Bible', to practise 'the priesthood of all believers' (not just an ordained few), and to do away with a set liturgy. The first meeting in England was in Plymouth in 1831, hence the title 'Plymouth Brethren'. Despite the aim of not having great leaders, these emerged, and around 1845 disagreements between them led to split into 'Open' and 'Exclusive' Brethren - the latter led mainly by J.N. Darby. (Since then there have been further splits, and today the most exclusive of the Exclusives are the PBCC who look to a leader in Australia.) The Exclusive Brethren required both partners to any marriage to be members, and anyone who married 'out' would be cast out of membership. At the same time, they did not want the secular state to have any part in their organisation (including their Meeting Rooms).

Not only had my parents-in-law married in a register office in 1938, but so too had at least some of their siblings. One Wright sister had married in Romford Register Office in 1922 and another had married a nurse on an ANZAC hospital ship at West Ham Register Office in 1918 and subsequently emigrated to New Zealand. ${ }^{175}$ For these early-to-mid twentieth century marriages - including the remarriage of my husband's maternal grandfather, who was widowed in his 50s and remarried at Bromley Register Office in 1954 - we have the benefit of family recollections. ${ }^{176}$ The couple and their families went to the local register office to have the formal legal ceremony. The bride would wear a smart dress and hat, or something more like a wedding-dress she had made herself - expensive white wedding dresses were frowned on. This was then followed by a party in one of their homes, where all the presents would be displayed, and by a Marriage Meeting at the Meeting Room (or a bigger venue) for all the guests and local (Exclusive) Brethren. Here there would be readings, prayers, and messages brought by any of the Brethren (although never Sisters) followed by an after-meeting tea; after which they all saw the couple off to their new home.

Of course, both partners had to be Exclusives. To facilitate this the Brethren organise national and international events to give young people the chance to meet. Since at least the 1950s anyone who married 'out' was not only cast out of membership but out of the family, too.

The marriages of all my husband's grandparents seem to have followed a similar pattern of marrying in register offices, followed by a Marriage Meeting. His maternal grandfather married for the first time in York Register Office in 1911. ${ }^{177}$ On the paternal side, Richard Wright (1859-1937, 
a customs officer) married Eleanor Russell in 1885 in Greenwich Register Office. ${ }^{178}$ Two of Richard's older sisters also married in St Pancras Register office - Emma in $1866^{179}$ and Ellen in $1878 .^{180}$

However, the picture changes for earlier generations. All my husband's great-grandparents were married after civil registration was established in 1837, but the only equivalent of a Register Office wedding is for his maternal great-grandparents who married in 1887 in a small village in France's Massif Central, home of the French 'assistante' he had met in York. ${ }^{181}$ A marriage in the Mairie was the only way of getting married in France, although it could be followed by a religious ceremony if the parties so wished. All the other great-grandparents married in a parish church 'according to the Rites and Ceremonies of the Church of England' - in Greenwich in $1840,{ }^{182}$ in Bermondsey in $1843^{183}$ and in Thornaby-on-Tees in $1878 .^{184}$

The 1840s marriages happened before the Brethren split, and therefore before one branch took a much more 'exclusive' line. But in both cases as with the 1870s marriage - it is quite likely that the families concerned had not yet been influenced by evangelists of a Brethren persuasion, or, if they had, may not yet have become members of a particular meeting. One clue might be the baptism of their children, if records could be found (or even exist): whilst the 'Open' Brethren practise adult baptism, the Exclusives baptise the children of members soon after they are born, in a simple ceremony in the home.

Understanding the religious traditions of our families is therefore essential to understanding their choices. This is one family among many but nonetheless a powerful example of how a register office wedding may be chosen because of the depth of the couple's faith, rather than a lack of it.

\section{Sex, lies and register office weddings}

\section{Valerie King}

On $18^{\text {th }}$ September 1877 Charles Watson married Ellen Stares ${ }^{185}$ in the Holborn register office. ${ }^{186}$ The Holborn Union had recently built new offices on Clerkenwell Road and the register office was located there, away from the workhouse itself. ${ }^{187}$ From the certificate it seems as if no one was present except those employed at the offices. It was signed by George Bilby and Walter B. James as Registrar and Deputy Superintendent Registrar respectively, and the witnesses were Arthur W. Hill, the Superintendent Registrar for the district, and Harry O. Hill, the clerk to the Poor Law Guardians.

It was not uncommon for register office staff - and even their families - to act as witnesses to a wedding. After all, being far away from family and friends seems to have been one of the reasons why couples married in a register office. The occupations listed for their respective fathers - a saddler and a farmer - hint that Charles and Ellen were not native to London: Charles had been born in Darlington, Durham in 1828: it was his work in the building trade that eventually took him to London. Ellen had been born in Grandborough near Winslow in Buckinghamshire in 1848. ${ }^{188}$

Nor was there anything in the legislation stipulating that witnesses should know the couple, or be able to verify the details that they had given. In this case this was just as well. They had sought to disguise the 20-year age gap between them by giving false details about their ages, with Charles being recorded as 45 and Ellen as 37. It was common for some liberty to be taken with the recording of ages if there was a substantial age gap between the new spouses. ${ }^{189}$

It also seems unlikely that they were living at different addresses as they claimed. Ellen had given birth to Charles' son, William Charles, on $2^{\text {nd }}$ August 1877, six weeks before their wedding. ${ }^{190}$ And their connection stretched back further still. In 1871 Charles had been living with a woman named Leah - who was Ellen's older half-sister. ${ }^{191}$

Leah had died in November 1875, ${ }^{192}$ not long before Charles and Ellen began their relationship. Although Leah had been described in the census as Charles' wife, no record of a marriage has been located. There was a very good reason why they might chosen to dispense with a ceremony: in 1850 Leah had married Edward Wilson, an agricultural labourer. ${ }^{193}$ The couple were still living together in $1851^{194}$ but by the time of the 1861 census were living separately. ${ }^{195}$ Divorce was unlikely to be an option, leaving Leah with a choice between bigamy and cohabitation in forming any new relationship. Had she and Charles been legally married, then this would have made Charles's subsequent marriage to Ellen void. ${ }^{196}$ The law, however, took no account of unformalised relationships in this context.

Ellen also had another secret to hide. In the 1881 census, Charles and Ellen are living at 19 Glasshouse Yard with their sons, William, now aged 4 and Albert, aged 2, and their niece 'Annie Fuskett' aged 10. ${ }^{197}$ Annie was in fact Ellen's illegitimate daughter, born when Ellen was living with 
her parents at the family home. Eight years later Annie herself married in Holborn register office, with Charles and Ellen as witnesses. ${ }^{198}$ Perhaps it was the fact that the groom was a widower that led them to choose the register office, or perhaps it was because of a further little cover-up - Annie had taken the surname of Watson and claimed Charles was her father. It does not appear to have been a lack of religious belief: William had probably been brought up a Methodist, and their family were regular Church of England goers all their lives.

In reality, Charles and Ellen - and Annie and William - could probably have avoided notice equally successfully by marrying in the parish church. In 1877874 marriages were celebrated in one of the three Anglican churches within the district, as compared to just 86 in the register office. ${ }^{199}$ Nonetheless, there does seem to have been a sense that a register office was the place to marry if one wanted to avoid too many awkward questions.

\section{A pregnancy and a register office wedding}

\section{Wendy Hamilton}

On 29 Sep 1877, Charles George Francis and Mary Jane Francis were married at the Register Office, Barton Regis, Gloucester. ${ }^{200}$ On the marriage certificate Charles was recorded as a Hay and Straw Dealer, aged 22, and Jane, as she was known, as a Cook Domestic Servant, aged 21. Their story underlines the variety of reasons that a couple might have for marrying in a register office - and for their choice of register office.

The first thing to note about their marriage is that it was in a different registration district - and indeed a different county - from their home parishes. Charles had been born in 1855 at Southover, Wells in the St Cuthbert In parish, and Jane in 1859 just 1.6 miles away in the village of Coxley in the parish of St Cuthbert Out. ${ }^{201}$

While both Charles and Jane had been baptised in the Anglican Church, throughout their lives they appeared to support both the Wesleyan Chapel and the parish church of Christ Church in Coxley. At this time the Wesleyan Chapel in Coxley, like many others within that denomination, was not registered for marriage. ${ }^{202}$ Yet this alone would not have led them to marry in a register office, let alone one in a different district. Most Wesleyans married in the Anglican church at this time, and some of their descendants were baptised and/or married at either an Anglican Church or a Wesleyan Chapel. ${ }^{203}$

Admittedly, Charles and Jane were first cousins - but marriages between cousins were (and are) perfectly legal, and in Victorian England they were common enough not to have attracted any adverse comment. ${ }^{204}$ So it seems unlikely that they married in a different district for this reason.

In fact, Jane may actually have been living in Barton Regis registration district at the time of her marriage. Her address - and indeed that of Charles - is shown on the marriage certificate as 21, Whiteladies Road, in the Clifton area of Bristol. The house is a handsome stone-built residence, in a neo-classical style. In 1879 it was occupied by a dental surgeon. It seems likely that if Jane was living there at the time of her marriage, it was as a servant - which makes it highly unlikely that Charles was living there with her. The more likely explanation is that this joint address was given as a matter of convenience. If they were both supposed to be living in the same district, then Jane could have given notice on behalf of both of them, and Charles could have simply travelled up to Bristol for the wedding itself.

At the time of their marriage Jane was actually 18 years of age, not 21 as recorded on the marriage certificate. Claiming to be 21 obviously avoided awkward questions about whether parental consent had been given. And while it does not appear that she was pregnant at the time of their marriage - their first child was born in Wells on 16 April 1879, over a year and a half later - there was another reason why they may have wanted to celebrate their marriage privately.

In December 1877 the local newspaper reported that Charles Francis had been summoned by Sarah Godsell Hopkins, of Southover, to show cause why an order should not be made upon him to contribute towards the maintenance of her illegitimate child, of which she alleged him to be the father. Sarah alleged that Charles had promised to marry her and that they had first had intercourse in October 1876, 'and frequently afterwards.' When, in the following February, she found herself pregnant, Charles asked her 'if she could not take something to destroy the child' and told her that 'it was not his intention to marry yet, as he wanted to see the county (sic) and should go to New Zealand.' He promised, however, that she 'should not be short of a $£ 5$ or a $£ 10$ note'. ${ }^{205}$

Whether or not Charles was the father of Sarah's child, her allegations would be of major concern. It seems likely that he would have preferred his marriage to Jane not be in a location where Sarah could cause a scene at the marriage or cause further embarrassment to Jane, both their 
parents and families. For Charles and Jane, as for many other couples, the register office provided a discreet venue where they would tie the knot.

\section{A puzzling register office marriage - and its prequel}

\section{Susan Donaldson}

When researching my great-grandparents William Henry Huband - known as Henry - and Sarah Jane Harvey, I was surprised by when, where, and how they had married. The wedding took place on 16 April 1878, with both stating that they were 28 years of age. It was celebrated in the registration district of Portsea Island, well over a hundred miles from where Sarah had been born in Birmingham, and where her family lived. ${ }^{206}$ And it took place in a register office. ${ }^{207}$

The reason for the location of the marriage was easily explained. Henry was a soldier with the Kings Royal Rifles and was living in Winchester Barracks. Having attained the rank of sergeant, he had been given permission to marry by his commanding officer. Following this Henry and Sarah were sent as a family to India where they remained for five years before returning to Winchester Barracks. My grandmother and three other siblings were born in India including twins who did not survive infancy.

Their age was higher than I had expected. In 1878 the average age at first marriage was 25.8 years for men and 24.4 years for women. ${ }^{208}$ But given that children were born at fairly regularly intervals after 1879 , I initially did not look further back to find out what had happened to Henry and Sarah in their twenties.

As regards the register office wedding, I assumed that Henry and Sarah must have opted for this because she had arrived from Birmingham without the time to establish residence and have the banns read. I was unable to discover whether Sarah was living locally for the required residence period, her address at the time being given simply as High Street, Portsmouth on the marriage certificate.

However, when I returned to researching them I discovered an earlier marriage. On 16 October 1870 Henry and Sarah had married in the Anglican Church of St Stephens in Birmingham. ${ }^{209}$ Henry was then employed as a Gun Barrel Sighter and Sarah as a Nail Cutter, presumably in a factory. Sarah was in fact three years younger than her stated age of 22; having been born in 1851, she was in fact just 19 at the time of her first wedding. Given that she is shown to be the same age as Henry in later documents this suggests she had no idea of her birth date or age. It also underlines the importance of verifying information given in public documents, given that they had aged only six years between 1870 and 1878 . I went on to discover that they had had two children - born in the first quarters of 1872 and 1873 respectively - who both had died in 1873 shortly after being baptised. ${ }^{210}$ The baptisms had taken place in March 1873 and 'Workhouse' was given as the family's place of residence. ${ }^{211}$

I was then able to obtain Henry's full army record. ${ }^{212}$ It showed that he had enlisted in January 1873 - just when the couple had one young child and another on the way and were in the workhouse with no other means of support. He was enlisted in the $60^{\text {th }}$ Rifles regiment, otherwise known as King's Royal Rifle Corps. In October 1873 he was posted to Nova Scotia, where he served for three-and-a-half years.

Significantly, he had described himself as single when he enlisted. It might well have been a fairly common occurrence for enlisted soldiers to declare themselves single men and possibly the army knew that this went on but were happy to keep recruiting. There was a tactical reason for this on both sides, as the army would only permit a small percentage of soldiers in each regiment to be married at any given time. ${ }^{213}$ Only those soldiers who had been given permission to marry would be recognised by the army, and such permission was only given after a certain length of service.

Henry and Sarah's commitment to each other during his posting to Canada was commendable. Given that Sarah was illiterate, whenever Henry wrote to her she would have needed someone to read the letters to her and write any replies. I can only guess that Sarah remained in Birmingham either in the workhouse or after finding work until she heard from Henry and joined him in Winchester after his deployment to Canada.

The thing that stands out for me about my Victorian ancestry is how mobile people were back then, perhaps more so than nowadays, driven by the need to find employment. Henry and Sarah obviously struggled initially when they were out of work and it seemed that all that was available to Henry was enlistment in the army. Happily, from a very difficult beginning Henry and Sarah became relatively prosperous in their later years. Henry retired from the army in 1900 and they moved to Willesden, in London, where the family lived until Henry's death in 1915. 
Their case also underlines the fact that the choice of a register office cannot be interpreted as evidence of a lack of religious faith. It is understandable that they chose the brief formality of exchanging prescribed words before a superintendent registrar and registrar when they had already been married for almost eight years.

\section{A just-in-time marriage in the register office}

\section{Bryan Grimshaw}

On Saturday $15^{\text {th }}$ June 1889, Walter James Grimshaw married Mary Ann Scarborough at Paddington Register Office. ${ }^{214}$ Exactly 7 days later, on $22^{\text {nd }}$ June, their first child was born. ${ }^{215}$

Walter James was 25 years old at the time of his marriage. He had been born in Walthamstow and, at the time of the 1881 census, he was still living at home, aged 17, employed as a gardener/domestic servant. ${ }^{216}$ By his marriage he was recorded as a coachman. His bride, Mary Ann Scarborough, gave her age as 26 , although I believe she was 27 . No occupation was given, which was not unusual, but in 1881 , when she was living with her family at Red Bridge Cottages, Barkingside, she had been employed as a general servant. ${ }^{217}$

Money was probably none too plentiful for this couple and so it is unsurprising that they chose to marry by the cheaper certificate, rather than the more expensive licence. Even marrying by certificate required a shilling to give notice, a shilling for the certificate authorising the marriage to go ahead, and five shillings to the Registrar at the time of the marriage. ${ }^{218}$ It was $£ 110$ s more for a licence, ${ }^{219}$ more than a week's wages for a working man at the time. The downside of marrying by certificate is that it involved a wait of three weeks between notice being given and the wedding going ahead. ${ }^{220}$

It is not known whether any family attended the wedding. The names of the witnesses do not match those of any known relatives. The suspicion that Walter and Mary were trying to marry as quietly as possible is reinforced by the different addresses that the couple gave at different times. The fact that the wedding was so quickly followed by a birth and a baptism allows us to track the couple across London - or at least to see where they wanted to be thought to be. At the time of the marriage Walter gave the address of 12 Craven Hill Mews, in Paddington. This was in fact where his elder brother Charles and his family lived. It may have been that he was lodging there with them. Alternatively, it would have been a convenient address for him to give to the superintendent registrar when giving notice of the marriage. Mary Ann, meanwhile, gave her address as 8 Craven Hill Mews. Virtually every house in Craven Hill Mews was occupied by a coachman or groom so perhaps brother Charles was able to arrange for her to lodge at, or use, this address. But again, one possibility is that she was not living there at all. No documentary proof of one's address was needed and the likelihood of any checks being made was a remote one.

Seven days after the wedding, when their son Walter John Grimshaw was born, the address given was 10 Portsea Mews, also in Paddington. Yet when Walter John was baptised three months later, on $6^{\text {th }}$ September 1889 , it was at St James parish church, Forest Gate. ${ }^{221}$ This time his father, still a coachman, gave his address as 37 Trevelyan Road, Forest Gate. This is where Mary Ann's sister and her family were living in 1891. Again, the question arises whether Walter and Mary were living there with them in 1889, or whether this was another address of "convenience".

By 1891 Walter John was staying with his maternal grandmother's family at Red Bridge Cottages, ${ }^{222}$ while his mother and father were living in a "coach house with rooms over" at Highbury Grove, Islington. ${ }^{223}$ Walter senior was still a coachman/domestic servant and their second child, Gertrude, was with them. Not until 1901 were the family all together at Red House Cottages (as Red Bridge Cottages had become), 2 doors from Mary Ann's mother. ${ }^{224}$ The answer may be that in 1889 they had had no real home to go to, perhaps just taking temporary lodgings so that their marriage - and the birth of their son - could take place as discreetly as possible.

\section{Married in a Register Office - or were they?}

\section{Jenny Paterson}

After their visit to Eton Register Office in February 1898 James and Beatrice had a Marriage Certificate ${ }^{225}$ - but were they actually married?

Although not blood relatives, Beatrice was the niece of James' former wife and therefore the couple were within the prohibited degrees of marriage. ${ }^{226}$ This meant that their marriage was void. So why did they go through a ceremony, and how did they do so undetected?

The events that led to this state of affairs started in 1895. James' first wife was nursed in her final illness by her sister, Mary, and probably at times by Mary's daughters - including Beatrice. Mary was present at the death and she registered the event in the local town, three days 
later. ${ }^{227}$ As well as caring for her sister, Mary would also have been keeping house for James during this period, so it was quite reasonable that Beatrice, who was herself recently widowed, should in turn keep house for James when he became a widower. That there was a 35 -year age difference made it seem a very suitable solution for both parties as it gave Beatrice a job, a home and an income and gave James the help he needed in the house. His grown-up sons were probably quite happy, as James continued to live in his own home so none of them had to have him living with them.

All was well for two and a half years but when Beatrice became pregnant by James in late 1897 the situation became untenable. Marriage was the only solution. To avoid any problems with their family and chapel rules they decided they would marry in a Register Office well away from their home town.

Beatrice turned to her elder sister, Alice, to help organise this. Alice had moved away from the area more than twenty years earlier, had been married twice and was at this time living in Windsor, almost seventy miles away from Beatrice's home near Southampton, and just across the river from Eton. Alice's husband had lived in Windsor for most of his life so had connections that enabled Beatrice to use an address in Eton Wharf when giving notice of her intended marriage at the Eton register office. ${ }^{228}$ Where the marriage was by licence, the law required notice to be given in the registration district where at least one the parties intending to be married had been resident for the previous 15 days. ${ }^{229}$ There was no need for notice to be given in the other party's district of residence. ${ }^{230}$

In giving notice she would have had to make a solemn declaration that she believed that there was 'no Impediment of Kindred or Alliance or other lawful Hindrance to the said Marriage. ${ }^{231}$ While the legislation governing marriage sternly warned that making a false declaration amounted to perjury, ${ }^{232}$ there was little chance of the impediment coming to light. As the couple had chosen to marry by licence, it was not necessary for the notice of marriage to be displayed in the register office. ${ }^{233}$ Even if it had been, it was unlikely that it would have been seen by anyone who knew them.

The ceremony duly took place on $16^{\text {th }}$ February, with Alice being one of the witnesses, and James and Beatrice returned to Park Gate to live as man and wife, with a certificate to prove it.

James' sons were horrified. Apart from anything else, Beatrice was their cousin and three of them had known her from the day she was born. It just did not seem possible that she was now their stepmother. They suspected the marriage was invalid in law and this made the situation even more difficult to accept.

Beatrice's baby was born at the end of April but the birth was not registered until June, just within the time limit. In the intervening period James, encouraged by his sons, was clearly looking into the legality of his marriage. Once the situation had been made clear he would have been told that he was not married in the eyes of the law.

This is supported by the fact that the Birth Certificate issued looks like that of an illegitimate child; Beatrice used her previous surname and James is not mentioned. ${ }^{234}$ At this time illegitimacy carried a significant social stigma, so this would not have been done out of choice. When two more children came along in 1900 and 1903, they were registered in the same way. James' Will also contains clear evidence of the illegality of the marriage. Beatrice is described as, 'Beatrice Elizabeth, with whom I have gone through the ceremony of marriage (hereinafter referred to as 'my said wife)" and her three children are described as 'reputed' throughout. However, the detail of the will makes it clear that James stood by Beatrice as she was the main beneficiary and his assets were distributed equally between his seven surviving children. ${ }^{235}$

It is probable that the wider village community never knew the true situation as Beatrice and all three children used James' surname throughout their lives. Beatrice was gradually accepted in the wider family and known as Auntie Beat and the children were included as cousins. Even so the family knew the secret and has passed it down through the generations.

\section{The Peculiar People - weddings and customs}

\section{Kathy Irvine}

My family has had a long-standing connection with the Peculiar People's Church, an offshoot of Methodism that emerged in the south-east of England in the mid-nineteenth century. The name may be unfamiliar to many, but it comes from the Bible: Peter's first epistle told his readers that they were 'a chosen generation, a royal priesthood, an holy nation, a peculiar people; that ye should shew forth the praises of him who hath called you out of darkness into his marvellous light'..$^{236}$ The movement emphasised the importance of a strict and literal reading of the Bible. ${ }^{237}$ 
My knowledge of these members of the family and their beliefs comes directly from my father. His father (1884-1960) was a pastor in the Peculiar People's Church. He had been born and raised on a farm near Rochford, Essex, where the work of the Church had begun, and he was brought up in the religion. He remained loyal (mostly) to the tenets of his religion his entire life and long after the religion had disbanded. My father was aware of his father's beliefs and was a regular visitor to his grandparent's home in Hawkwell, Essex. He was often accompanied by his younger brother and they also met up with other church members, giving them an insight into church matters.

The surname of my paternal great-great grandmother (who came from Great Wakering) was one that had been associated with the Peculiar People congregation in its early days when services were held at Daws Heath, Thundersley, and the religion was at its height of popularity. It is possible that our family connection to this religion began there.

Daws Heath was the chapel of choice in my family, and I was told it was a very long walk across fields to attend the service. On Sundays, services were held three times a day and my great-grandparents attended them all. However, they would not have been able to marry there, as the chapel was not registered for marriage until the $1920 \mathrm{~s}^{238}$

When my paternal great-grandfather (1858-1923) married for the first time on 30 November 1882, it was in the parish church of Great Sutton in Essex. ${ }^{239}$ He was 24 and an engine driver. His bride was 22 and a domestic servant. Both partners were adherents of the Peculiar People's faith and devout, but it is not clear when they joined the congregation. It seems likely that they were members by 1900, when they were both prosecuted and found guilty of wilful neglect of their 15 -year-old daughter. ${ }^{240}$ She had had rheumatic fever which caused "inflammation of the heart". It is possible that diphtheria was an added threat to her health at the time and a church elder had been called in to administer faith healing, one of the central beliefs of the movement being divine healing without any medical assistance; no medical assistance was sought, and their daughter died. Both were sentenced to one month's hard labour or a fine of five pounds each. They chose the fine. ${ }^{241}$

My great-grandmother died in 1913 and my great-grandfather remarried in 1915. This marriage took place in the Register Office, Rochford, Essex on 19 April 1915; ${ }^{242}$ both partners had been widowed. The groom was 56 and the bride 53 . I believe both partners were members of the church of the Peculiar People. Pictures of my great-grandfather's second wife show her clothing to be very severe, with a dark (or black) dress and bonnet. No flesh, apart from the face, shows. My father did tell me that this was common among the women who belonged to the Peculiar People's church. There didn't appear to be a dress code for the men, but pastors did wear a black coat.

My Grandfather's first marriage, to a local spinster, had actually taken place in that same Register Office, in $1913 .{ }^{243}$ He was 30 and his occupation Traction Engine Driver. The bride was 33. There is no information about the bride's religious belief but I assume the pair were like minded and probably met through their shared religion. She died in London in 1918, a victim of the flu epidemic. My grandfather remained in London. There were no children.

My grandfather's second marriage - to my grandmother - took place in London, at St Mary's, Wandsworth, in $1921 .{ }^{244} \mathrm{He}$ was 36 and an engineer and she was 28 and worked as domestic servant/ companion. By that time the religion was in decline. In any case, I assume it would have been the wish of my grandmother to have her wedding take place in a church. My grandmother did not adhere to any of the ideals of the Peculiar People; she was particularly skeptical of faith healing and was not an adherent of any of the other tenets (no drinking, gambling, etc). As my dad recalled, when church matters were discussed, his father would tell him and his brother that none of this should get back to their Mum!

The marriages of my great-grandparents and grandfather illustrate the complex relationship between faith and other factors in determining where couples married. At the time they married, none of the churches of the Peculiar People had been registered for marriages - although one, at Rayleigh in the registration district of Rochford, was actually registered a few weeks after my great-grandfather's second wedding. ${ }^{245}$ Like many other members of smaller denominations, they did not in practice have the option of marrying according to their own religious rites, many decades after this had become an option in theory.

\section{Married Or Not? A Catholic Bride's Two Ceremonies}

\section{Margaret French}

When Frederick Thomas Crosbie married Ellen Bolam ${ }^{246}$ by certificate at the Newcastle Register Office on $31^{\text {st }}$ July $1915^{247}$ they could not have imagined the interest it would arouse over a century later. He was not a young soldier marrying his sweetheart before leaving for the Western Front but a mature, recently widowed father of four small children while Ellen was a single mother of similar age. A marriage of convenience 
perhaps? We shall never know and the interest in this marriage lies elsewhere for Frederick was a Scottish born Presbyterian and Ellen a Catholic. Why would Ellen marry in a Register Office?

There had been a time when the law required that all non-conformists and Catholics marry in the Anglican church. ${ }^{248}$ This restriction was lifted by the 1836 Marriage Act which allowed these two groups to be married in their own places of worship as well as making it possible for nonreligious civil marriages to be held in register offices. Thus by the time Frederick and Ellen married in 1915 there was no legal reason to prevent their marrying in a Catholic church. So why the Register Office? The marriage certificate shows nothing particularly untoward although Ellen was less than truthful regarding her parentage, her father being shown as James, a deceased journeyman tailor. Her labourer father, Peter, was very much alive and living in the family home in Gateshead. Perhaps the choice of the Register Office was a compromise given their respective religious affiliations.

The late nineteenth and early twentieth centuries had seen widespread questioning by Modernists of "sacred authority, the interpretation of Sacred Scripture, and the principal mysteries of Faith" resulting in a Papal Decree in 1907. ${ }^{249}$ In the same year, the laws pertaining to Catholic marriage were also tightened. On $2^{\text {nd }}$ August 1907 the decree Ne Temere was issued, coming into force on Easter Sunday April $19^{\text {th }} 1908^{250}$ and states quite clearly that "Marriages .... between a Catholic and a non-Catholic (mixed marriages) are declared to be invalid unless the marriage be celebrated before the Catholic bishop or priest of the place, or priest delegated by him" and "in the presence of at least two witnesses". The decree also required that the marriage was to be noted in the baptismal register and if the baptism took place elsewhere then the marriage details were to be forwarded to the parish where the baptism took place. ${ }^{251}$ For Ellen, therefore, the marriage in the Register Office was invalid in the eyes of her church.

We cannot know If Ellen was aware of this fact but what is certain is that she and Frederick went through a second marriage service on $12^{\text {th }}$ June 1916 by which time Ellen was expecting their first child. Where mixed marriages are concerned it is not unique to have two ceremonies but they are usually on the same day or very close in time to each other. For example, on 9 January 1851 Sydney Kennedy and Adelaide Helene Ullathorne were married by English Presbyterian rites in the Little Portland Street Chapel, Marylebone followed by a Catholic ceremony at the Catholic Chapel Holland Street (St Mary Abbott's Chapel), Kensington, conducted by William Ullathorne, the Catholic bishop of Birmingham. $^{252}$

The marriage certificate for Frederick and Ellen shows they were married after Banns in the Anglican parish church of St Michael, Byker ${ }^{253}$ with the same family details although Frederick is now Frederick Muir. ${ }^{254}$ There was, in 1916, a Catholic church in which they could have married making their union valid in Catholic Canon law. Building had began on the Catholic church of St Lawrence around 1887 and it was consecrated in $1907 .{ }^{255}$ The question is why did they not do so?

Certainly Ellen's family would have disapproved of both the non-Catholic marriage and a child born out of wedlock. The fact that a second marriage took place at all nearly a year after the first suggests that the couple were taking steps to con-validate their union. It is entirely possible that the couple simply chose the wrong church. For Ellen the mistake, if such it was, meant that while both marriages were invalid in Catholic Canon law she remained firmly married according to English law.

The tale does not end happily as, ironically, Ellen obtained a divorce in 1921 on the grounds of Frederick's adultery and bigamy. She died in 1922 aged 39.

From Jenny Witney to Noliny R. Gupta: a mixed marriage in the register office

\section{Mike Sadler}

On 9 December 1915 Jenny Witney got married in Kensington Register Office. Her age was given as 21, although she was actually only 18, having been born on 28 June 1897. Like many other young men and women before and since, it seems likely that she would have claimed to be of age in order to avoid difficult questions about whether she had obtained parental consent to her marriage. It may also be significant that her surname was recorded as 'Whitney' - a minor discrepancy that may simply have been a clerical error, but may also have been another smokescreen. At the time of the wedding she was already three months' pregnant, and her new husband was Raghunath Backrishna Gupta, 9 years her senior. ${ }^{256}$

Their backgrounds could not have been more different. Jenny had been born in a small village in Buckinghamshire called Lee Common, not far from Amersham. This area was mainly farming and agricultural. Jenny's father, James Witney, was a farmer and pheasant breeder, and they lived in a small cottage in an area called Field End, part of The Lees. The family consisted of 3 boys and 3 girls, Jenny being the youngest. Tragically, in 1904, when Jenny was 7, her father was killed in a carting accident, aged only 42. 
Jenny's two older sisters Florence (my grandmother) and Maud left home for London to work as house/scullery maids in large houses in Hampstead. This was pretty much the norm in those days as work was scarce in the countryside and with no father, times were hard. Jenny soon followed her sisters up to London and obtained a position at the department store Selfridges, aged just 16 . Perhaps it was here that she met Raghunath.

Tracing his early life is more of a challenge. Was he, as stated in the local press, descended from an ancient Hindu family, a branch of the Imperial Gupta Dynasty? ${ }^{257}$ On the marriage certificate it simply states 'student' with his father as Balkrishna Gupte, a Museum Superintendent. Gupta is spelt variously with an 'e' or an ' $a$ ' at the end, and it is difficult to know which is correct. In any case, it is a very common name. He was one of several hundred Indian students in the UK at the time ${ }^{258}$ and as such it is reasonable to assume that he came from an educated middleclass background.

After the marriage Jenny adopted the name Noliny R. Gupta. Although Jenny was a Christian she declared that she was a Hindu by nationality. ${ }^{259}$ This may have been her take on the fact that a wife acquired her husband's domicile upon marriage and that for all legal purposes she would be regarded as domiciled in India, even though she had never left England. She also said that Christ was an oriental from Asia, and there were no 'watertight compartments' between East and West. ${ }^{260}$ There were, however, no mosques, temples or gurdwaras registered for marriage at this time. ${ }^{261}$ Some Indian students converted to Christianity and married in the Anglican church, but for couples of mixed faith the register office was the only option.

Jenny might have read in the newspapers of the high-profile breakdown of some of these marriages. ${ }^{262}$ Sadly, we will never know whether Jenny and Raghunath's union would have proved more longlasting. Six months after the wedding Jenny gave birth to their son, Nana Pasa James Gupta, but after the confinement she became very weak. When she showed no sign of improving, a decision was made to move her from their home in London to the family cottage in Field End. ${ }^{263}$ Raghunath was in Manchester on business and was summoned by telegram. Not realising how ill Jenny was, Raghunath went on down to London on urgent business.

On Friday 25 July, at 1.30am, Jenny passed away. Her death certificate states the cause of death as 'Acute pulmonary tuberculosis and exhaustion' and gives her correct age of 19. Her elder sister, Maud, was with her, and Jenny's final words were 'I desire to be with Jesus'.

\section{A remarriage according to the rites of the Methodist Church, 1940'264}

\section{Jenny Gordon}

On 8 August 1940 Dr. John Harburn and Evelyn Mortimer were married at the Methodist chapel in Higher Buxton. John was a widower, while Evelyn was described as 'formerly the wife of Walter Frank Mortimer, from whom she obtained a divorce.'265

Evelyn's first marriage had been to Walter Mortimer in 1913 at St James Church (now demolished) in Buxton. Walter Mortimer proved to be a ne'er do well; a very unsatisfactory husband to Evelyn and father to three children. He had a very casual attitude towards work and maintaining his family, disappearing at regular intervals and only coming back to ask for money. For some time Evelyn and the children lived with her parents in Buxton. When Walter turned up as he sometimes did, Evelyn's father would not allow him in the house. Evelyn trained as a masseuse and established a practice on Hall Bank in Buxton. Her father Samuel James, to whom she was very close, supported her financially in this venture. In November 1938, Evelyn obtained a divorce from Walter Mortimer on the grounds of desertion. ${ }^{266}$ She would have been among the first wave to obtain a divorce on the basis of desertion: before the Matrimonial Causes Act 1937 adultery was the sole ground for divorce. ${ }^{267}$

Her second husband was very different. John had left school at the age of 14 and went to work as errand-boy to a chemist. Wanting to take on work in the shop as well, he taught himself Latin and chemistry, often falling asleep over his late-night studies. As time went on, he took on various medical roles, and in the end had advanced far enough to go and study medicine at Glasgow University. He either started or joined a medical practice in Buxton with a Dr Potter. He took a great interest in the properties of the thermal springs, becoming an expert in the treatment of those who came to take the waters from various parts of the country, and writing a monograph on the composition of the waters. He became a magistrate, ending up as Chairman of the Bench, and was a very active member of the Wesley Chapel, serving as a local (lay) preacher for many years. He seems to have been well-acquainted with Evelyn's family for some time: when Evelyn's father died in 1931 the obituary notice in the Buxton Advertiser expressly noted that Dr Harburn 'was unable to attend' his funeral. This suggests that they knew one another. 
Given Dr Harburn's connections to the Methodist Chapel, it is unsurprising that they should have chosen to marry there. In any case, Evelyn's divorce would have been a bar to her remarrying in the Anglican church: the expansion of the grounds for divorce in the 1937 Act had been accompanied by a provision allowing the Church of England to refuse to solemnise the marriage of any person whose previous spouse was still alive, regardless of whether they had been divorced by them or obtained the divorce from them. ${ }^{268}$ Prior to this, clergy had only been able to refuse to conduct a marriage if the person had been divorced on the basis of their adultery. ${ }^{269}$

The ceremony was performed by Thomas Miller, who was the father of Dr Harburn's daughter-in-law Ruth. He and Dr Harburn were good friends and had a high regard for each other. Given that Thomas would not have been the minister of the chapel in 1940, it is likely that he conducted the ceremony because of this personal connection. He had been the Superintendent Minister of the Buxton circuit, stationed at Wesley, from 1924 to 1930. After that, following the Methodist pattern of itinerant ministry, he had worked in other circuits, but came back to retire in Buxton. At that point he probably served as a supernumerary minister in the Buxton circuit (i.e. a retired minister who is not counted in the number of ministers allotted to the circuit).

As far as the law was concerned, however, the more important person - whose name is squashed under Miller's, reflecting the fact that the form was not designed for two people to sign in this space - was Joseph Mace, authorised person for the chapel. Joseph was also a Methodist minister, ${ }^{270}$ but this was not a requirement to be appointed to this role. The key role of the authorised person was to ensure that the marriage was registered. A marriage had to be celebrated in the presence of - but not necessarily by - an authorised person. ${ }^{271}$

John and Evelyn's marriage thus illustrates how flexible the law was in terms of who conducted the marriage - as compared to where it was celebrated and who was responsible for registering it. It also reflects a number of trends that were to become increasingly important in determining how marriages were solemnised in the mid-twentieth century - the expansion of the grounds for divorce, the bar on marrying in the Church of England, and the more welcoming approach of non-conformist churches. ${ }^{272}$

\section{A Baptist wedding in a Methodist Chapel, 1946}

\section{Christine Brumbill}

On 14 January 1946 my parents, Colin and Marjorie, got married in the Methodist Church on Alexandra Road in Longport, then a village in the township of Burslem in Staffordshire. ${ }^{273}$

They had met through Colin's sister Cynthia, who had been studying at the Underwood Secretarial College in neighbouring Hanley in 1937-38, at the same time as Marjorie. On 16 November 1942, Colin and Marjorie got engaged prior to Colin leaving to go overseas with the army. He was then 20 and she was 21. During the war Marjorie worked as a Costing Clerk at Billington and Newton, Longport who were performing War work, while Colin served in North Africa and Italy, including Anzio.

In 1945 Colin, by then a Lance Corporal, was in Egypt, but he was given 28 days' leave and on 26 December 1945 set off from Port Said. He must have written to Marjorie to let her know that he would be coming home on leave after Christmas. Given that their marriage took place by certificate, this signifies that she must have given notice of their intention to marry no later than Christmas Eve: under the Marriage and Registration Act 1856, notices of marriage had to be displayed in the office of the superintendent registrar for 21 clear days. ${ }^{274}$ There was no requirement that these should be 21 working days, though - so even if the office was closed over Christmas this would not have mattered.

As Colin was overseas it is understandable that all the arrangements had to be carried out by Marjorie and her relatives. While Colin was a member of the Church of England, I recall that he was not very religious and so he would have had no objection to marrying where Marjorie wished.

The twist in the story is that Marjorie was not a Methodist at all, but had been brought up as a Baptist. However, as she later told me, there was not a Baptist Church in Burslem. In fact, there had been a Baptist Church there - a large building, capable of seating 370, situated on the High Street. But it does not appear that it was registered for marriages: no announcement of it being so has been found in the London Gazette. In any case, in 1944 it had burnt down, and its few remaining members worshipped either at Hanley or at Newcastle. ${ }^{275}$

However, the Methodist church in Longport seems to have been very accommodating. The marriage certificate recorded that the wedding was conducted by the Reverend Harry Brindley. He was Marjorie's uncle, and a practising Baptist minister. He was accompanied by Raymond T. Heard, Methodist minister, the authorised person for registering the marriage at the Methodist Church. The law required that the authorised 
person be present at the ceremony, that certain prescribed words should be exchanged in their presence, and that they should register it. ${ }^{276}$ It did not require the authorised person to conduct the ceremony, although those who were also ministers would usually do so. ${ }^{277}$ Both the Baptist and Methodist ministers signed the marriage certificate, capturing this example of co-operation between different denominations and illustrating the flexibility of the law.

Marjorie appears to have made her own dress - which is still up in my loft to this day - possibly with the help of her relatives. As Marjorie's father had died some years earlier, it appears that her Uncle Harry Williams gave her away; his daughter Ruth was one of the witnesses. The other witness was Colin's father, and the best man was Cynthia's husband, who served in the RAF and wore his uniform to the wedding. Despite Marjorie being an orphan - her mother had died in 1945 - the wedding was clearly very much a family affair.

Colin and Marjorie managed to squeeze in a honeymoon for six nights at the Queens Hotel, Kendal in the Lake District, which is where one of his aunts and her husband lived. On his return to the Potteries at the end of his leave, he set off and returned to Egypt.

\section{A post-war wedding in the Register Office}

\section{Peter Zimmermann}

Edith Lilian Hall and Fritz Zimmermann met on a Shropshire farm where Fritz was a German Prisoner of War (POW) and Lilian was a Land Girl. It wasn't long before love began to blossom.

On weekends when they weren't working they went on clandestine bicycle rides together, Lilian somehow having contrived to get hold of civilian clothing for Fritz. By law they weren't allowed to go out together as British girls could not fraternise with 'aliens'. When the POW Camp Commandant heard about this, Fritz was ordered back to camp, given 28 days' detention and had to repeatedly dig a hole and fill it in. He came off lightly as some German POWs were imprisoned for breaking this law. ${ }^{278}$

Such legislation infuriated the headstrong Lilian, who got permission from the farmer to travel to the War Office in London. There she demanded to have a meeting with someone 'high up'. Amazingly her request was granted; the following day (in July 1947) the law relating to fraternisation was relaxed. ${ }^{279}$ Lilian later said it was all due to her intervention, and perhaps really believed it!

Not long after the start of their romance, Lilian asked Fritz to marry her. He said he didn't know what to do as he was likely to be repatriated to Germany, and that he would only marry her if she was under 30 , as he was only 26 . Her response was that she was 30.

Lilian and Fritz were duly married in Manchester Register Office on $2^{\text {nd }}$ September $1947 .{ }^{280}$ Fritz was described as a Bachelor aged 25 , a Farm Labourer and his address was Hoarstone Farm, Market Drayton, Shropshire (where he worked). He had previously applied for civilian status which had been granted on $5^{\text {th }}$ August 1947 (just less than a month before their marriage) and released him from Prisoner of War status. It is likely that he was one of the first former POWs to marry an English woman.

Lilian was described as Land Girl 598944 W.L.A., and as a Spinster aged 30. She was in fact 35. Her address was given as 11 Albermarle Road, Withington, Manchester - her parents' home - and her parents were the witnesses. After the wedding Lilian's parents gave them temporary accommodation in their home, and clearly approved of the match.

There are a number of possible reasons why Lilian and Fritz married in a Register Office. The first is that one or both of them had lost their faith. Lilian had attended Sunday school, and both had been confirmed as teenagers - Fritz in the Lutheran Church and Lilian in the Church of England. Confirmation may have been a rite of passage, but the services would have been overtly Christian.

Both, however, had relatives with strong views about religion who may have influenced them. Lilian's younger sister was very far left in her political views and possibly a Communist Party member. Fritz's father described himself as a Freidenker (free-thinker). The family were active Social Democrats and were ardent opposers of Hitler's regime, so much so that Fritz's father was arrested for speaking publicly against Hitler and Nazism. He was released from the prison cells the following day to be told that if he spoke like that again in public, he wouldn't be seen again. He didn't change his views, but was more subtle in expressing them. 
A second reason may have been that they wanted to avoid a public church wedding. Even two years after the end of the war it was possible that it was frowned upon for an English woman to marry a former enemy. Lilian might also have wanted to avoid the local parish church where she had been confirmed and where the vicar would no doubt have known her true age.

A final and more mundane reason may have been lack of money. In the years after the end of the war, people didn't have lots of spare money, so Lilian and Fritz may have decided on a civil wedding on the grounds of economy. While the legal costs did not differ significantly, there was no expectation of buying special wedding clothes for a Register Office wedding at this time. They wore 'posh' clothes as indicated by the photos of the wedding - best suits, Lilian wearing a hat, bouquet and buttonholes.

I'll never know the real reason, though - which is a salutary reminder about the challenges of recreating even the recent past. Lilian and Fritz were my parents, and yet I can't remember if I ever asked them why they chose to marry in a Register Office. As with the millions who had done so before them, they would have had their own reasons, which we can only try to reconstruct.

\section{Crossing the denominational divide: Authorised persons and the registration of weddings in Desborough's Nonconformist chapels}

\section{Rebecca Probert and Liz Harris}

From 1899 Nonconformist chapels were for the first time given the option of holding their own official marriage registers. This possibility was brought about by the Marriage Act 1898, which marked an important change in the way marriages were regulated. And those registers cast light on how the law governing weddings in Nonconformist chapels operated in practice.

Here we focus on three congregations in the Northamptonshire town of Desborough. Each represents a different tradition within Nonconformity, as well as illustrating the changes within those traditions: one was Wesleyan Methodist; another initially described itself as Independent, but adopted the term Congregationalist upon moving to a new building in 1913; the third originally described itself as 'Particular Baptist' but changed its designation to simply 'Baptist' when a new chapel was built in 1927.

While it had been possible for Nonconformists to get married in their own places of worship since 1837, providing these had been registered for the purpose, the Marriage Act 1836 had required that a civil registrar be present. This requirement was much resented, and after a prolonged campaign the Marriage Act 1898 permitted the trustees or other governing authorities of registered places of worship to appoint their own 'authorised person' to register the marriages that were celebrated there. ${ }^{281}$ Upon appointing an authorised person, the registered place of worship would be issued with its own official marriage register.

All three congregations in our study were fairly quick to avail themselves of the option of appointing their own 'authorised persons'. ${ }^{282}$ The register book for the Wesleyan Methodist chapel begins in 1901, that for the Independent chapel in 1903, and that for the Particular Baptist chapel in 1910. The fact that the Wesleyan Methodists were the first to register comes as no surprise. It had been the Wesleyans who had campaigned the hardest to dispense with the presence of the civil registrar at their weddings. Across the country as a whole, they were more likely to appoint an authorised person than any other denomination, accounting for around half of the 1,495 in post by the end of 1900. By contrast, just over one-quarter of these first authorised persons were Congregational or Baptist. ${ }^{283}$

It should be noted that it was the responsibility of the authorised person to be present at a wedding, to hear the parties make the declarations and vows prescribed by law, to ensure that the marriage was duly registered, and to send copies of all entries in the marriage register to the local superintendent registrar every quarter. The authorised person did not, however, necessarily conduct the wedding and did not have to be a minister. He (or even she) might simply be a trusted member of the congregation. Perhaps unexpectedly, while an authorised person had to be appointed in relation to a specific building, their authorisation extended to any other place of worship that had been registered for marriages within the registration district. ${ }^{284}$ It did not even need to be of the same denomination. During the passage of the 1898 Act there had been a suggestion that individuals should only be authorised to officiate in places of worship 'belonging to the same religious denomination'. ${ }^{285}$ This, however, had been roundly rejected by the leading Nonconformist MP Carvell Williams. As he argued:

I think it would be highly objectionable if, for instance, a Congregational minister were not allowed to perform the marriage ceremony in a Wesleyan chapel. It is altogether foreign to Nonconformist feeling and Nonconformist practice, and I do not think it requires further argument. ${ }^{286}$

The clear implication was that Nonconformists would be willing to co-operate and would not be deterred from doing so by denominational divisions. 
And Desborough's chapels provide an excellent example of such co-operation. In each of them, once an authorised person had been appointed there were no further examples of marriages being conducted in the presence of a registrar. The evidence of the registers suggests that there would have been little need to call on the civil authorities, given the willingness of authorised persons from different denominations to attend when needed. In the Baptist chapel, for example, weddings were on occasion registered by the authorised persons for the Toller chapel in Kettering and the Methodist chapel in Desborough.

Co-operation between different places of worship, and between the different denominations, was also evident in the identity of the ministers conducting weddings. There are numerous examples of weddings being conducted by a minister from a different place of worship. Weddings in the Wesleyan Methodist chapel were on a number of occasions conducted by the ministers for Kettering's Wesleyan Silver Street chapel and Rockingham Road chapel. In the Congregational chapel, there are examples of weddings being conducted by the minister for the Independent chapel in Rothwell, some two miles away, by the minister of the Toller chapel in Kettering, and by the minister of Desborough's Methodist church. The name that appears most often in that register, however, is that of Desborough's Baptist minister, who conducted weddings in the Congregational chapel in 1915, 1917, 1919, 1923-25, 1929, 1942, and 1946-48. The favour was then returned, since for much of 1930 through to 1932 most weddings in the Baptist chapel were attended by Desborough's Congregational minister, and between 1937 and 1946 he conducted a further 22 weddings there. Another wedding in the Baptist chapel was conducted by the minister of Kettering's Carey Baptist church. It is striking, though, that both the Baptist and Congregational churches were more likely to call on each other's ministers than on a minister of their own denomination from a different town.

For the family historian, whether a marriage was registered by a civil registrar or by an authorised person might seem like a purely technical point, unlikely to cast any light on the choices of the couple getting wed. But the statistics suggest that at least some couples may have been making a positive choice to marry in a registered place of worship that had its own authorised person. By 1919, a disproportionate number of weddings in registered places of worship were taking place in the presence of an authorised person. ${ }^{287}$ This could, of course, simply have been because more popular places of worship were more likely to appoint an authorised person in the first place. But it is also possible that at least some Nonconformist couples deliberately chose to marry in a chapel with its own authorised person even if it was not their usual place of worship. Knowing the law that underpinned such marriages may therefore help to explain what might otherwise be puzzling findings regarding the location of wedding ceremonies and the people who were present.

\section{References}

1 These included the Devon Family History Society, the Peak District U3A, the Upper Dales Family History group, the Isle of Wight Family History Society, and the Odiham U3A Family History Group.

2 The collection of such data was approved by the Research Ethics Committee at the University of Exeter (Ref 201920-095).

3 Probert, Rebecca (2021) Tying the Knot: The Formation of Marriage, 1836-2020. Cambridge: Cambridge University Press, forthcoming.

4 Office for National Statistics, 'Marriages in England and Wales 2017' (14 April 2020) table 1: 'Number of marriages by type of ceremony and denomination, 1837 to $2017^{\prime}$

5 On the way in which the data was collected, see 'Introduction'

6 Marriage Act 1836. (6\&7 Will 4, c. 85) s.18; Births and Deaths Registration Act 1837, s

7 Thirteenth Annual Report of the Registrar General of Births, Marriages and Deaths in England. London: H.M.S.O., 1852, Table VII.

8 See Snell, K.D.M. and Ell, Paul S. (2000) Rival Jerusalems: the Geography of Victorian Religion. Cambridge: Cambridge University Press. Appendix A.

9 Marriage Act 1840 (3\&4 Vict. c.72), s.2.

10 Email from Janet Freeman, 7 August 2020

11 London Gazette, 30 October 1849

12 See further Probert, Rebecca 'A Catholic couple in the register office.' Further examples of weddings being recorded in this way were supplied by Pauline Gilbertson and Lesley Plant.

13 See e.g. 'Marriages', Western Times, 6 October 1837; Trewman's Exeter Flying Post, 7 September 1837

14 See e.g. Gloucester Journal, 22 July 1837; Stamford Mercury 25 Aug 1837; Royal Cornwall Gazette, 29 December 1837.

15 Each party was required simple to state 'I do solemnly declare, That I know not of any lawful Impediment why I [name] may not be joined in Matrimony to [name]. and I call upon these Persons here present to witness that I [name] do take thee [name] to be my lawful wedded Wife [or Husband]': Marriage Act 1836. (6\&7 Will 4 c. 85) s.20

16 Marriage Act 1836. (6\&7 Will 4, c. 85) s.20.

17 Email from Mary Ratcliffe, 16 June 2020.
18 See Smith, Joan, 'Susan Darke: a puzzling chapel marriage'.

19 Calculated from ONS, 'Marriages in England and Wales 2017', table 1.

20 See Probert, Rebecca (2009) Marriage Law and Practice in the Long Eighteenth Century: A Reassessment. Cambridge: Cambridge University Press. An example was provided by Robyn Coghlan (Catholic couple married in Manchester Cathedral in 1825).

21 Probert, Marriage Law and Practice, ch. 9.

22 Examples of pre-1837 marriages were provided by Barbara Cole, Tom Flintham, and Peter Wood.

23 Norfolk News, 29 March 1845. Example provided by Colyn Storer.

24 Example provided by Colyn Storer.

25 Example provided by Andrew R. Janes.

26 Davies, Rupert, George, A. Raymond and Rup, Gordon (1978) (eds) A History of the Methodist Church in Great Britain: Vol 2. London: Epworth Press, 1978.

27 See further Probert, Tying the Knot.

28 Email from John Williams, 15 June 2020.

29 Email from Pauline Gilbertson, 13 June 2020

30 Email from Joan Marshall, 11 June 2020

31 Email from Mary Ann Dunn, 12 June 2020.

32 Marriage and Registration Act 1856. (19\&20 Vict. c.119) s.12.

33 Marriage and Registration Act 1856. (19\&20 Vict. c.119) s.11.

34 Email from Judith Gurney, 1 September 2020

35 Liverpool Mercury, 1 September 1886.

36 Sixty-second Annual Report of the Registrar General of Births, Marriages and Deaths in England. London: H.M.S.O., 1901. Table 6.

37 'Marriages in England and Wales 2017', table 1

38 Field, Clive (2019) Periodizing Secularization: Religious Allegiance and Attendance in Britain, 1880-1945. Oxford: Oxford University Press, p. 48.

39 London Gazette, 16 November 1888.

40 Email from Judith Cooper, 12 June 2020.

41 Email from Margaret French, 15 June 2020

42 Thirty-seventh Annual Report of the Registrar General of Births, Marriages and Deaths in England. London: H.M.S.O., 1876. Table 9.

43 Sixty-second Annual Report of the Registrar General of Births, Marriages and Deaths in England. London: H.M.S.O., 1901. Table 6. 
44 Email from Sally Davies 15 June 2020

45 Emails from Marion Moverley, 1 July 2020 (marriages in 1857, 1882), Janet Freeman 8 July 2020 (marriage in 1875); Victoria Dyke, 11 July 2020 (marriage in 1884).

46 Email from Liz Kemshead, 14 June 2020.

47 Email from Janet Freeman, 8 July 2020.

48 Email from Andrew R Janes, 4 August 2020.

49 https://www.genuki.org.uk/big/eng/NFK/Barsham_East.

50 I am grateful to Sally Davies for bringing this chapel to my attention.

51 Email from Irene Wilkinson, 14 June 2020. Crich Chapel was registered for marriages a few years later: see London Gazette, 8 December 1908.

52 Irvine, Kathy, 'The Peculiar People'

53 Wright, Jill, 'The Plymouth Brethren and Register Office Marriages'.

54 Emails from Colin Moretti, 6 July 2020; Victoria Dyke, 11 July 2020.

55 Probert, Tying the Knot, chapter 4.

56 Email from Marilyn Tilley, 17 June 2020.

57 Field, table 9.2.

58 Email from Tony Hunt, 3 August 2020.

59 Emails from Valerie King, 27 June 2020, Tony Hunt, 3 August 2020.

60 Marriage to deceased wife's niece: emails from Mary Barry, 21 June 2020; Janet Findlay, 3 July 2020. Marriage to deceased wife's daughter: emails from Carol Abbott, 13 June 2020; Lesley Plant, 20 June 2020.

61 Calculated from Office for National Statistics, 'Marriages in England and Wales 2017' (14 April 2020), table 2: 'Number of marriages by previous marital status, 1845 to $2017^{\prime}$

62 Email from Mary Ann Dunn, 12 June 2020

63 Email from Barbara Phillips, 23 November 2020.

64 Marriages in England and Wales 2017', table 1.

65 Email from Kay Winfield, 22 June 2020.

66 Email from Pat Phillips, 9 July 2020.

67 Email from Madeleine Cook, 14 June 2020; further examples were provided by Colin Moretti, 6 July 2020, and Barbara Lee, 8 July 2020

68 See further French, Margaret, 'Married or Not?'.

69 'Marriages in England and Wales 2017', table 1.

70 Calculated from 'Marriages in England and Wales 2017', table 2.

71 Calculated from 'Marriages in England and Wales 2017', table 2.

72 Gordon, Jenny, 'A remarriage according to the rites of the Methodist Church, 1940 .

73 Wright, Jill, 'The Plymouth Brethren and Register Office Marriages'

74 Email from Kate Holloway, 16 June 2020, giving details of weddings in 1908, 1921 and 1931.

75 Email from Sarah Hughes, 5 July 2020.

76 Sadler, Mike, 'From Jenny Witney to Noliny R Gupta: a mixed marriage in the register office'

77 Probert, Tying the Knot, ch 6.

78 Field, Periodizing Secularization

79 Email from Tony Allen, 13 June 2020

80 The undenominational 'Church of Christ' had been built in Above-Bar St in Southampton in 1880 and registered for marriages the following year: see Page, William, ed. (1908) A History of the County of Hampshire: Volume 3. London, Victoria County History. pp. 524-537. http://www.british-history.ac.uk/vch/hants/vol3/ pp524-537: accessed 15 May 2021; London Gazette, 16 December 1881.

81 Email from Valerie King, 27 June 2020.

82 Zimmermann, Peter, 'A post-war wedding in the Register Office'.

83 Field, Periodizing Secularization, table 9.2.

84 Email from Kathy Irvine, 17 June 2020.

85 Example provided by Margaret Spiller, 12 September 2020.

86 Anon (1907) Enquire within Upon Everything. London: Madgwick, Houlston and Co Ltd, $104^{\text {th }}$ ed. para. 1465.

87 Laverack, Elizabeth (1979) With this ring.... 100 years of Marriage. London: Elm Tree Books.

88 Marriages (CR). BRADY, Thomas and HETHERINGTON, Mary. Certified Copy of an Entry of Marriage in the Registration District of Salford given by the GRO 26 May 2020.

89 Third Annual report of the Registrar-General of births, deaths and marriages in England. London: HMSO, 1841

90 The Tablet, 30 May 1840.

91 Marriage Act 1836. (6\&7 Will. 4, c.85) s.4.

92 Marriage Act 1836. (6\&7 Will. 4, c.85) s.11.

93 Marriage Act 1836. (6\&7 Will. 4, c.85) s. 7.
94 Probert, Tying the Knot, ch. 3.

95 The Tablet, 30 May 1840

96 Ex p Brady (1840) 8 Dowl. 332

97 Stone, Lawrence (1995) A History of the Making and Breaking of Marriage in England. Oxford: Oxford University Press. p. 133.

98 Probert, Tying the Knot, ch. 3.

99 Marriage and Registration Act 1856. (19\&20 Vict. c.119) s.12.

100 Probert, Interpreting choices'.

101 Marriage Act 1840. (3\&4 Vict. c.72) s.2.

102 lbid.

103 Marriages (CR). RULE, James and JONES, Mary. Certified Copy of an Entry of Marriage in the Registration District of Falmouth given by the GRO 26 January 2011.

104 The Cornwall Register (Bodmin; Liddell \& Son. 1847), p. 81.

105 Marriage Act 1823. (4 Geo. 4, c.76) s.22.

106 Marriage Act 1823. (4 Geo. 4, c.76) s.2.

107 Kelly, Bernard W (1907) Historical Notes on English Catholic Missions. London: Kegan Paul, Trench, Trübner \& Co.

108 The Church of Christ the Salt of the Earth. A Sermon Preached in St Michael's Church, Helston, at the Triennial Visitation of the Lord Bishop of Exeter, August 1, 1842, by the Rev. W-J. Coope, M.A. of Brasenose College, Oxford; and Rector of Falmouth.

109 The Spectator, 8 February 1845

110 The Spectator, 8 February 1845

111 Marriage Act 1836. (6\&7 Will. 4, c.85) s.4.

112 Eighth Annual report of the Registrar-General of births, deaths and marriages in England. London: H.M.S.O., 1848.

113 Births (CR) England. RULE, William Charles Jones. Certified Copy of an Entry of Birth in the Registration District of Falmouth given by the GRO 15 May 2017.

114 Census records. England. Falmouth, Cornwall. 6 June 1841. RULE, James. PN HO107/154. ED 9. FL 12. p. 17. https:ancestry.co.uk: accessed 15 May 2021.

115 Robson's Cornwall Directory 1839. pp. 5, 18. https://www.ancestry.co.uk: accessed 15 May 2021.

116 Baptisms (NCR) England. Chesham, Buckinghamshire. 30 April 1826. ALLWRIGHT, John. Registers of Births, Marriages and Deaths Surrendered to the Non-Parochial Registers Commissions of 1837 and 1857; RG4/318. https://www.ancestry.co.uk: accessed 15 May 2021.

117 Bucks Herald, 21 February 1880.

118 Bucks Herald, 3 April 1880, 15 April 1882

119 Page, William, ed. (1925) A History of the County of Buckingham: Volume 3. London: Victoria County History. pp. 203-18. https://www.british-history.ac.uk/vch/bucks/ vol3/pp203-218: accessed 15 May 2021.

120 London Gazette, 29 August 1837, recording its registration on 21 August 1837.

121 Marriages (CR). ALLWRIGHT, John, and HAWES, Mary. Certified Copy of an Entry of Marriage in the Registration District of Amersham given by the GRO 23 October 2000.

122 Baptisms (NCR) England. Chesham, Buckinghamshire. Registers of Births, Marriages and Deaths surrendered to the Non-parochial Registers Commissions of 1837 and 1857; RG4/249. Chesham Old Meeting House - Baptist.

123 Census records. England. Amersham, Buckinghamshire. 6 June 1841. DORRELL, James. PN HO107/45, Book 3. ED 3. FL 8. p. 11. https:www.ancestry.co.uk: accessed 15 May 2021.

124 Deaths index (CR) England \& Wales. RD Amersham. $1^{\text {st }}$ Q., 1849. ALLWRIGHT, Mary. Vol. 6. p. 260. https://www.ancestry.co.uk: accessed 15 May 2021. Births index (CR) England \& Wales. RD Amersham. $1^{\text {st }}$ Q., 1849. ALLWRIGHT, Maurice. Vol. 6. p. 363. https://www.ancestry.co.uk: accessed 15 May 2021. Deaths index (CR) England \& Wales. RD Amersham. $1^{\text {st }}$ Q., 1849. ALLWRIGHT, Maurice. Vol. 6. p. 260. https://www. ancestry.co.uk: accessed 15 May 2021.

125 Marriages (CR). ALLWRIGHT, John, and SAYWELL, Susannah. Certified Copy of an Entry of Marriage in the Registration District of Amersham given by the GRO 24 April 1985.

126 Post Office Directory of Berkshire, Northamptonshire and Oxfordshire; with Bedfordshire, Buckinghamshire and Huntingdonshire. London: Kelly \& Co, 1854. http://specialcollections.le.ac.uk/digital/collection/p16445coll4/id/167099/: accessed 15 May 2021.

127 Deaths index (CR) England \& Wales. RD Amersham. $1^{\text {st }}$ Q., 1862. ALLWRIGHT, Susan. Vol. 3a. p. 236. https://www.ancestry.ac.uk: accessed 15 May 2021

128 Marriages (CR). ALLWRIGHT, John, and HOVEY, Elizabeth. Certified Copy of an Entry of Marriage in the Registration District of Amersham given by the GRO 23 February 2002. 
129 Census records. England. Amersham, Buckinghamshire. 7 April 1861. HOVEY, Eliza. PN RG9/845, FL 28. p. 19. https://www.ancestry.co.uk: accessed 15 May 2021; Census records. England. Amersham, Buckinghamshire. 3 April 1881. ALLWRIGHT, Elizabeth. PN RG11/1451. FL 87. p .2. https://www.ancestry.ac.uk: accessed 15 May 2021.

130 Marriages (PR) England. St Luke, Finsbury, Islington. 18 August 1828. HOVEY, John, and BARBER, Elizabeth. London Metropolitan Archives. London Church of England Parish Registers. P76/LUK/041. https://www.ancestry.co.uk: accessed 15 May 2021.

131 Deaths index (CR) England \& Wales. RD Amersham. $1^{\text {st }}$ Q., 1882. ALLWRIGHT, Elizabeth. Vol. 3a. p. 338. https://www.ancestry.co.uk: accessed 15 May 2021.

132 Marriages (CR). ALLWRIGHT, John, and CATO, Elizabeth. Certified Copy of an Entry of Marriage in the Registration District of Amersham given by the GRO 9 September 2009

133 Kelly's Directory of Buckinghamshire. London, Kelly's Directories Ltd, 1883. p. 17. http://specialcollections.le.ac.uk/digital/collection/p16445coll4/id/8866/: accessed 15 May 2021.

134 Deaths index (CR) England \& Wales. RD Amersham. $1^{\text {st }}$ Q., 1912. ALLWRIGHT, Elizabeth. Vol. 3a. p. 994. https://www.ancestry.co.uk: accessed 15 May 2021.

135 Deaths index (CR) England \& Wales. RD Aylesbury. $1^{\text {st }}$ Q., 1912. ALLWRIGHT, John. Vol. 3a. p. 1486. https://www.ancestry.co.uk: accessed 15 May 2021.

136 Marriage Act 1836. (6\&7 Will 4, c. 85) s.20. See Probert, Rebecca. (2018). A Uniform Marriage Law for England and Wales. Child and Family Law Quarterly p. 259 for discussion of the registrar's role.

137 Marriage Act 1836. (6\&7 Will 4, c. 85) s.20.

138 Marriage Act 1836. (6\&7 Will 4, c. 85) s.20. See Probert, 'Interpreting choices' for the form of words required.

139 Marriages (CR). FARRANT, Charles, and VICARY, Charlotte. Certified Copy of an Entry of Marriage in the Registration District of Honiton given by the GRO 22 October 2009.

140 Births (CR) FARRANT, Thirza. Certified Copy of an Entry of Birth in the Registration District of Honiton given by the GRO 3 December 2008

141 Marriages (CR). DEEM, James, and FARRANT, Charlotte. Certified Copy of an Entry of Marriage in the Registration District of Exeter given by the GRO 10 March 2020.

142 Offences Against the Person Act 1828. (9 Geo. 4, c.31) s.22.

143 The offence of bigamy did not extend to 'any Person marrying a Second Time, whose Husband or Wife shall have been continually absent from such Person for the Space of Seven Years then last past, and shall not have been known by such Person to be living within that Time': Offences Against the Person Act 1828. (9 Geo. 4, c.31) s.22.

144 Probert, Rebecca (2012). Marriage Law for Genealogists. Kenilworth: Takeaway Publishing. p. ${ }^{* *}$

145 Marriage Act 1836. (6\&7 Will 4, c. 85) ss.4, 7 and 11

146 Marriage Act 1840. (3\&4 Vict. c.72) s.2.

147 London Gazette, 12 September 1852; Exeter Journal and Almanac. Exeter, 1853, http://specialcollections.le.ac.uk/digital/collection/p16445coll4/id/64285/: accessed 15 May 2021; London Gazette, 25 February 1859.

148 As required by Marriage Act 1836. (6\&7 Will 4, c. 85) s.6.

149 Marriage and Registration Act 1856. (19\&20 Vict. c.119) s.4.

150 Probert, Rebecca, and D'Arcy-Brown, Liam, 'Workhouse weddings' (in preparation).

151 Census records. England. Honiton, Devon. 7 April 1861. PAGE, James. PN RG9/1379. FL 10. p. 2. https://www.ancestry.co.uk: accessed 15 May 2021.

152 Census records. England. Honiton, Devon. 2 April 1871. PAGE, James Deem. PN RG10/2042. FL 59. p. 3. https://www.ancestry.co.uk: accessed 15 May 2021.

153 Marriages (CR) England. RICE, Edwin and HAWKER, Elizabeth. Certified Copy of an Entry of Marriage in the Registration District of Stoke Damerel given by the GRO 30 August 2014.

154 Twenty-Second Annual Report of the Registrar General of births, deaths and marriages in England. London, H.M.S.O, 1861. Table III.

155 Twelfth Annual Report of the Registrar General of births, deaths and marriages in England. London, H.M.S.O, 1851. Abstract of Marriages.

156 Census records. England. St Thomas, Devon. 7 April 1861. RICE, Edwin. PN RG9/ 1386. FL 23. p. 15. https://www.ancestry.co.uk.

157 Marriage and Registration Act 1856. (19\&20 Vict. c.119) ss.2 and 6

158 Marriage and Registration Act 1856. (19\&20 Vict. c.119) s.10.

159 Marriage and Registration Act 1856. (19\&20 Vict. c.119) s.9.

160 Non-church records were surrendered to the newly created General Register Office and their admissibility as evidence was confirmed by the Non-Parochial Registers Act 1840 .

161 London Gazette, 6 October 1837

162 First Annual report of the Registrar-General of births, deaths and marriages in England. London: H.M.S.O., 1839. p. 5
163 Marriages (CR) England. NEWBERRY, Matthew, and DARKE, Mary Ann. Certified Copy of an Entry of Marriage in the Registration District of Honiton given by the GRO 21 August 2004.

164 Baptisms (NCR) England. Honiton, Devon. 2 January 1821. DARKE, Susan. Registers of Births, Marriages and Deaths Surrendered to the Non-Parochial Registers Commissions of 1837 and 1857; RG 4/441, https://www.ancestry.co.uk: accessed 15 May 2021

165 Census records. England. Honiton, Devon. 6 June 1841. DARKE, Susan. PN HO107/ 200. ED 3. FL 7. p.10. http://www.ancestry.co.uk: accessed 15 May 2021.

166 Census records. England. Honiton, Devon. 30 March 1851. DARKE, Susan. PN HO107/1863. FL 147. p. 6. https://www.ancestry.co.uk: accessed 15 May 2021.

167 Census records. England. Sidmouth, Devon. 7 April 1861. DARKE, Susan. PN RG9/ 1380. FL 31. p. 19. https://www.ancestry.co.uk: accessed 15 May 2021.

168 Marriages (CR) England. COLESWORTHY, John, and DARKE, Susan. Certified Copy of an Entry of Marriage in the Registration District of Honiton given by the Honiton registry office on 4 October 2003.

169 The first Independent chapel in Sidmouth to be registered for marriages was the Marsh Chapel. By 1858 this had fallen into disuse and the Independent Chapel at Western Town was registered in its place: London Gazette, 20 July 1858

170 Probert, Tying the Knot, ch 3.

171 Ibid.

172 Probert, Rebecca, 'A Catholic marriage in the register office.'

173 Census records. England. Topsham, Devon. 7 April 1861. COOPER, James. PN RG9/ 1386. FL 43. p. 4. https://www.ancestry.co.uk: accessed 15 May 2021

174 Marriages (CR) WRIGHT, William Smart and GRAY Ursula Mary. Original Certificate of Marriage in Lambeth Registry Office issued on 27 July 1938.

175 WRIGHT, WS private diaries, entries for 23 March 1918 recording marriage of his sister Eleanor WRIGHT to John Stanley CAMPION in West Ham and for 18 February 1922 recording marriage of his sister Harriet WRIGHT to Albert Edwin DOBBS in Romford, Essex.

176 Marriages index (CR), England \& Wales. RD Bromley, Kent. $4^{\text {th }}$ Q., 1954. GRAY, Percy Willis and SANDERSON, Grace. Vol. 5b p. 248. https://www.ancestry.co.uk: accessed 19 May 2021. WRIGHT family memories of attending the ceremony on 24 November 1954

177 Marriages (CR) GRAY, Percy Willis and WELLS, Sarah Louise. Original Certificate of Marriage in the Register Office in the district of York issued on 11 August 1911.

178 Marriages (CR) WRIGHT, Richard and RUSSELL Eleanor. Certified copy of an Entry of Marriage in the Registration District of Greenwich in the County of Kent given by the GRO 11 April 2007.

179 Marriages index (CR), England \& Wales. RD Pancras, London. $1^{\text {st }}$ Q., 1866, Vol. 18, p. 217. TUGGY, Henry and WRIGHT Emma E. http://search.findmypast.co.uk: accessed 18 December 2014 (date given as 13 February 1866 at the Register Office, St Pancras in 'The Parents of Dear Mother and Father' - unpublished memoir by Fanny Wright (1864-1947) typescript dated 1937)

180 Marriages (CR) HENRY, Thomas and WRIGHT, Ellen. Original Certificate of Marriage in the Registration District of Pancras in the County of Middlesex issued on 19 September 1878.

181 Marriages (CR) France. WELLS, William and DOREL Lea. Estrait des Registres de l'Etat Civil de la Commune de Pont de Montvert (Lozere) Le 11 Août 1875

182 Marriages (CR) WRIGHT, Edward and BUER Harriot. Certified copy of an Entry of Marriage in the Parish of Greenwich, County of Kent given by the GRO on 4 October 2005

183 Marriages (CR) RUSSELL, George Edward and WHEATLEY Louisa. Certified copy of an Entry of Marriage in the Parish of Bermondsey, County of Surrey, given by the GRO 8 June 2006

184 Marriages (CR) GRAY, Thomas and WILLIS Elizabeth. Certified copy of an Entry of Marriage in the Parish Church of Thornaby in the County of York given by Deputy Interim Registrar of Thornaby on 29 September 2005.

185 Also spelled Steares or Stairs.

186 Marriages (CR). WATSON, Charles and STARES, Ellen. Certified Copy of an Entry of Marriage in the Registration District of Holborn given by the GRO 23 June 2020.

187 http://www.workhouses.org.uk/Holborn/

188 Census records. England. London City. 3 April 1881. WATSON, Charles. PN RG11/ 373. FL 82. p. 31. https://www.ancestry.co.uk: accessed 15 May 2021.

189 Probert, 'Interpreting Choices'.

190 Baptisms (PR). WATSON, William Charles. Islington, St Mark Myddleton, Square London Metropolitan Archives, Church of England Births and Baptisms, P76/MRK 005. https://www.ancestry.co.uk: accessed 15 May 2021.

191 Census records. England. London City. 2 April 1871. WATSON, Charles. PN RG10/ 420/ FL 66. p.20. https://www.ancestry.co.uk: accessed 15 May 2021. 
192 Deaths index (CR) England \& Wales. RD London City. $4^{\text {th }}$ Q., 1875. WATSON, Leah. Vol. 1c. p. 11. https://ancestry.co.uk: accessed 15 May 2021.

193 Marriages (PR) England. St Giles, South Mimms, Middlesex. 27 October 1850. WILSON, Edward and STEARS, Leah. London Metropolitan Archives, London Church of England Parish Registers, DRO/005/A/01/011. https://www.ancestry.co. uk: accessed 15 May 2021

194 Census records. England. Barnet, Middlesex. 30 March 1851. WILSON, Edward. PN HO107/1701. FL 195. p.51. https://www.ancestry.co.uk: accessed 15 May 2021.

195 Census records. England. East London, London. 7 April 1861. WILSON, Leah. PN RG9/213. FI 76. p.43. https://www.ancestry.co.uk: accessed 15 May 2021

196 Marriage Act 1835

197 Census records. England. London City, London. 3 April 1881. WATSON, Charles. PN RG11/373. FL 82. p. 31. https://www.ancestry.co.uk: accessed 15 May 2021

198 Marriages (CR). UGLOW, William Ernest, and WATSON, Annie. Certified Copy of an Entry of Marriage in the Registration District of Holborn given by the GRO 9 July 2009 .

199 Fortieth Annual Report of the Registrar General of births, deaths and marriages in England. London: H.M.S.O., 1879

200 Marriages (CR). FRANCIS, Charles George, and FRANCIS, Mary Jane. Certified Copy of an Entry of Marriage in the Registration District of Barton Regis given by the GRO 8 August 2003.

201 Census records. England. Wells, Somerset. 5 April 1891. FRANCIS, Charles G. PN RG12/1913. FL 68. p.4. https://www.ancestry.ac.uk: accessed 15 May 2021.

202 The London Gazette, 8 October 1895, subsequently recorded that the Wesleyan Chapel at Coxley was registered for marriages on 3 October 1895.

203 Probert, 'Tying the Knot'.

204 Davidoff, Leonore (2006) "Close Marriage" in the Nineteenth and Twentieth Century Middle Strata'. In Ebtehaj, F., Lindley, B., and Richards, M., eds. Kinship Matters. Oxford: Hart. pp 19-46.

205 Wells Journal, 13 December 1877.

206 Sarah was illegitimate, her mother having gone on to marry in St Philip's Parish Church in Birmingham in 1854. There followed a large number of half siblings for Sarah

207 Marriages (CR) England. HUBAND, William Henry and HARVEY, Sarah Jane. Certified Copy of an Entry of Marriage in the Registration District of Portsea given by the GRO on 26 July 2007.

208 Forty-First Annual Report of the Registrar General of births, deaths, and marriages in England. London: H.M.S.O., 1880

209 Marriages (PR) England. St Stephens, Birmingham. 10 October 1870. HUBAND, William Henry and HARVEY, Sarah Jane. Anglican Parish Records, Library of Birmingham, DRO 11/1A; Archive Roll M68. https://www.ancestry.co.uk: accessed 15 May 2021.

210 Deaths index (CR). England \& Wales. RD Birmingham, Warwickshire. $2^{\text {nd }}$ Q., 1873. HUBAND, George. Vol. 6d. p. 141. https://www.ancestry.co.uk: accessed 15 May 2021; Deaths index (CR). England \& Wales. RD Birmingham, Warwickshire. $3^{\text {rd }}$ Q. 1873. HUBAND, Frances Harriet. Vol. 6d. p. 119. https://www.ancestry.co.uk: accessed 15 May 2021

211 Baptisms (PR). Birmingham, St Martin. HUBAND, Frances Harriet and HUBAND George. 28 March 1873. Library of Birmingham, Birmingham Church of England Parish Registers; DRO 34/28; Archive Roll: M107. https://www.ancestry.co.uk: accessed 15 May 2021.

212 Royal Hospital Chelsea: Soldiers Service Documents; PN WO 97: https://www.fold3. com/image/587736834

213 Venning, Annabel (2005) Following the Drum: The Lives of Army Wives and Daughters. London: Headline Review, p. 15, puts the figure at around 6 per cent.

214 Marriages (CR) England. GRIMSHAW, Walter James, and SCARBOROUGH, Mary Ann. Certified Copy of an Entry of Marriage in the Registration District of Paddington given by the GRO on 15 June 1998.

215 Births (CR) England. GRIMSHAW, Walter John. Certified Copy of an Entry of Birth in the Registration District of Paddington given by the GRO on 14 January 2011.

216 Census records. England. Walthamstow, Essex. 3 April 1881. GRIMSHAW, Walter J. PN RG11/1732. FL 16. p. 25. http://www.ancestry.co.uk: accessed 15 May 2021.

217 Census records. England. Romford, Essex. 3 April 1881. SCARBOROUGH, Mary A. PN RG11/1746. FL 8. p. 10. https://www.ancestry.co.uk: accessed 15 May 2021

218 Marriage Act 1836. (6\&7 Will 4, c. 85) ss. 5, 7 and 12.

219 Marriage and Registration Act 1856. (19\&20 Vict. c.119) s.10.

220 Marriage Act 1836. (6\&7 Will 4, c. 85) s.7.

221 Baptisms (PR) England. St James, Forest Gate, Essex. 6 September 1889. GRIMSHAW, Walter John.
222 Census records. England. Romford, Essex. 5 April 1891. GRIMSHAW, Walter. PN RG12/1369. FL 8. p. 10. https://www.ancestry.co.uk: accessed 15 May 2021.

223 Census records. England. Islington, London. 5 April 1891. GRIMSHAW, Walter. PN RG12/174. FL 126. p. 14. https://www.ancestry.co.uk: accessed 15 May 2021.

224 Census records. England. Romford, Essex. 31 March 1901. GRIMSHAW, Walter J. PN RG13/1651. FL 103. p. 20. https://www.ancestry.co.uk: accessed 15 May 2021.

225 Marriages (CR). NEWBURY, James and DIMMICK, Beatrice Elizabeth. Certified Copy of an Entry of Marriage in the Registration District of Eton given by the GRO 24 June 2020

226 Marriage Act 1835. (5\&6 Will. 4, c.54) s.2.

227 Deaths (CR). NEWBURY, Charlotte. PDF Copy of an Entry of Death in the Registration District of Fareham given by the GRO Jan 2019.

228 Where the marriage was by licence, the law required notice to be given in the registration district where at least one the parties intending to be married had been resident for the previous 15 days: Marriage and Registration Act 1856. (19\&20 Vict. c.119) s.2. There was no need for notice to be given in the other party's district of residence.

229 Marriage and Registration Act 1856. (19\&20 Vict. c.119) s.2.

230 Marriage and Registration Act 1856. (19\&20 Vict. c.119) s.6.

231 Marriage and Registration Act 1856. (19\&20 Vict. c.119) s.2.

232 Marriage and Registration Act 1856. (19\&20 Vict. c.119) s.2.

233 Marriage and Registration Act 1856. (19\&20 Vict. c.119) s.5.

234 Births (CR). DIMMICK, Douglas. PDF Copy of an Entry of Birth in the Registration District of Fareham given by the GRO 3 July 2020.

235 Will of James Newbury dated $19^{\text {th }}$ March 1912. probatesearch.service.gov.uk: accessed 15 July 2020.

2361 Peter 2: 9 (King James Version, emphasis added).

237 See https://www.uec-churches.net/history/.

238 London Gazette, 18 February, 1921, records that it was registered for marriages on Valentine's Day.

239 Marriages (CR) BARNES Henry and DOCURA MACE Mary. Certified copy of marriage in the Registration District of Rochford given by the GRO 19 March 1982.

240 Chelmsford Chronicle, 22 June 1900

241 I assume the church paid the fine; I cannot imagine my great grandparents would have so much money available to them on their own account.

242 Marriages (CR) BARNES William and THORNLEY Caroline. Certified copy of marriage in the Registration District of Rochford given by the GRO 10 May 2013.

243 Marriages (CR) BARNES Arthur and TAYLOR Ellen. Certified copy of marriage in the Registration District of Rochford given by the GRO 10 May 2013.

244 Marriages (CR) BARNES Arthur and HALSEY Doris. Certified copy of marriage in the Registration District of Wandsworth 6 February 1921

245 London Gazette, 7 May 1915

246 Full name Margaret Ellen on her birth certificate and entry in the baptismal register at St Joseph's church, Gateshead.

247 Marriages (CR). CROSBIE, Frederick Thomas and BOLAM, Ellen. Certified Copy of an Entry of Marriage in the Registration District of Newcastle upon Tyne given by the GRO 24 June 2020.

248 The Clandestine Marriages Act 1753 which decreed that, in England and Wales, only marriages that were performed by the Church of England as well as Jews and Quakers would be legally recognised. This meant that many different religions including the Catholic had to conform to the Anglican rites.

249 Lamentabili Pope Pius X 1907 through the Congregation of the Council.

250 Ne Temere Pope Pius X August 1907 through the Congregation of the Council.

251 lbid.

252 Permission to quote details of the marriage courtesy of $\mathrm{Mr}$ and Mrs Graham Howlett.

253 Marriages (CR). CROSBIE, Frederick Muir, and BOLAM, Ellen. Certified Copy of an Entry of Marriage in the Registration District of Newcastle upon Tyne given by the GRO 24 June 2020 .

254 Different documents give his name variously as Frederick Thomas, Frederick Muir, Frederick Thomas Muir and plain Thomas. His birth and death certificates confirm his name as Frederick Thomas.

255 Communication from Father Sean O'Neill, St Teresa's church, Heaton, Newcastle. July 2020.

256 Marriages (CR). GUPTA, Raghunath Backrishna AND WHITNEY, Jenny. Certified Copy of an Entry in the Marriage Register obtained from the GRO 29 June 2012

257 Bucks Herald, 2 September 1916.

258 Visram, Rozina (2002) Asians in Britain: 400 Years of History. Pluto Press, 88.

259 As reported in Bucks Herald, 2 September 1916. 
260 lbid.

261 Probert, Tying the Knot.

262 Probert, Tying the Knot, ch. 6.

263 Field End cottage was, after doing some research, a very small cottage, with no running water or electricity. It is unclear why the family thought it best to move a very sick person from Kensal Green in London, where they lived, to a remote farm cottage in the middle of the countryside.

264 With thanks to Joyce Engmann who read and commented on the case study in draft.

265 Marriages (CR). HARBURN, John and MORTIMER, Evelyn. Certified Copy of an Entry of Marriage, 8 August 1940.

266 When he died, Walter Mortimer had a pauper's funeral.

267 Probert, Rebecca (2015). Divorced, Bigamist, Bereaved: The family historian's guide to marital breakdown, separation, widowhood and remarriage from 1600 to the 1970s. Kenilworth, Takeaway.

268 Matrimonial Causes Act 1937. (1 Edw. 8 \& 1 Geo. 6, c.57), s.12.

269 Divorce and Matrimonial Causes Act 1857. (20\&21 Vict. c. 85) s.57.

270 See the database of Methodist ministers held by the University of Manchester: https://www.library.manchester.ac.uk/search-resources/special-collections/guideto-special-collections/methodist/using-the-collections/index-of-methodist-minis ters/m/

271 Probert, Rebecca (2018). 'A Uniform Marriage Law for England and Wales'. Child and Family Law Quarterly 259.

272 See further Probert, Tying the Knot, ch. 7.
273 British War Office GSGS 4127, Ordnance Survey Popular and New Popular Editions: 110 - Stoke on Trent (1945). https://www.visionofbritain.org.uk/maps: accessed 15 May 2021.

274 Marriage and Registration Act 1856. (19\&20 Vict. c.119) s.4.

275 Jenkins, JG, ed. A History of the County of Stafford: Volume 8. London: Victoria County History. pp. 276-307. http://www.british-history.ac.uk/vch/staffs/vol8/ pp276-307: accessed 15 May 2021.

276 Marriage Act 1898. (62\&63 Vict., c. 58) ss. 4, 6, 7.

277 Probert, 'A Uniform Marriage Law'.

278 See Moore, Bob. (2013). Illicit Encounters: Female Civilian Fraternization with Axis Prisoners of War on Second World War Britain. Journal of Contemporary History p. 742.

279 lbid.

280 Marriages (CR). ZIMMERMANN, Fritz, and HALL, Edith Lilian. Certified Copy of an Entry of Marriage in the Registration District of Manchester given by the GRO 2 September 1947.

281 Marriage Act 1898. (62\&63 Vict., c. 58) s 4.

282 Marriage Act 1898. (62\&63 Vict., c. 58) s 4.

283 Sixty-Third Annual Report of the Registrar-General. London. H.M.S.O., 1902. pp. vi-viii. 284 Marriage Act 1898. (62\&63 Vict., c. 58) s 6 (3).

285 Hansard. HC Deb 15 June 1898, vol 59 col 349

286 lbid.

287 Eighty-second Annual Report of the Registrar-General. London. H.M.S.O., 1921. p. xxiv and Table XII.

\section{ABOUT THE AUTHOR}

Rebecca Probert is Professor of Law at the University of Exeter. Her research focuses on the law and history of marriage, bigamy, divorce and cohabitation and she is the author of numerous articles and books, including Marriage Law and Practice in the Long Eighteenth Century: $A$ Reassessment (2009), The Legal Regulation of Cohabitation: From Fornicators to Family, 1600-2010 (2012) and Tying the Knot: The Formation of Marriage 1836-2020 (2021), all published by Cambridge University Press. She has also published a number of guides for family historians, including Marriage Law for Genealogists (2012) and Divorced, Bigamist, Bereaved? (2015). She has appeared numerous times on TV and radio, including Harlots, Heroines and Housewives, A House Through Time and Who Do You Think You Are? 